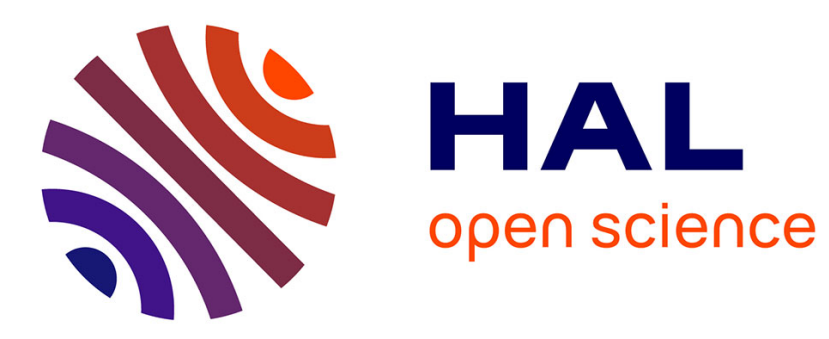

\title{
High-Resolution Large Eddy Simulation of Snow Accumulationin Alpine Terrain
}

\author{
V. Vionnet, E. Martin, Valéry Masson, C. Lac, F. Naaim-Bouvet
}

\section{To cite this version:}

V. Vionnet, E. Martin, Valéry Masson, C. Lac, F. Naaim-Bouvet. High-Resolution Large Eddy Simulation of Snow Accumulationin Alpine Terrain. Journal of Geophysical Research: Atmospheres, 2017, 122 (20), pp.17. 10.1002/2017jd026947 . hal-02606584

\section{HAL Id: hal-02606584 https://hal.inrae.fr/hal-02606584}

Submitted on 16 May 2020

HAL is a multi-disciplinary open access archive for the deposit and dissemination of scientific research documents, whether they are published or not. The documents may come from teaching and research institutions in France or abroad, or from public or private research centers.
L'archive ouverte pluridisciplinaire HAL, est destinée au dépôt et à la diffusion de documents scientifiques de niveau recherche, publiés ou non, émanant des établissements d'enseignement et de recherche français ou étrangers, des laboratoires publics ou privés. 
Journal of Geophysical Research: Atmospheres

\section{RESEARCH ARTICLE \\ 10.1002/2017JD026947 \\ High-Resolution Large Eddy Simulation of Snow Accumulation in Alpine Terrain}

Key Points:

- Snow accumulation is simulated with

a fully coupled snowpack/atmosphere model

- Riming influences small-scale snowfall pattern in alpine terrain

- Wind-induced snow transport is the main source of spatial variability

Correspondence to:

V. Vionnet,

vincent.vionnet@meteo.fr

\section{Citation:}

Vionnet, V., Martin, E., Masson, V.,

Lac, C., Naaim Bouvet, F.,

\& Guyomarc'h, G. (2017).

High-resolution Large Eddy

simulation of snow accumulation in

alpine terrain. Journal of Geophysical

Research: Atmospheres, 122.

https://doi.org/10.1002/2017JD026947

Received 10 APR 2017

Accepted 24 AUG 2017

Accepted article online 29 AUG 2017

\author{
Vincent Vionnet ${ }^{1}$ iD, Eric Martin ${ }^{2,3}$ (D), Valéry Masson² ${ }^{2}$ Christine Lac $^{2}$, Florence Naaim Bouvet ${ }^{4}$, \\ and Gilbert Guyomarc' ${ }^{1}$
}

${ }^{1}$ CNRM, CEN, Météo France/CNRS, UMR 3589, Grenoble, France, ${ }^{2}$ CNRM, Météo France/CNRS, UMR 3589, Toulouse, France, ${ }^{3}$ IRSTEA, Aix en Provence, France, ${ }^{4}$ Université Grenoble Alpes, IRSTEA, UR ETNA, Saint Martin d'Hères, France

\section{Introduction}

Snow distribution in alpine terrain is strongly variable and depends on the elevation, steepness, aspect, and wind exposure of mountain slopes (e.g., Schirmer et al., 2011). This strong variability results from processes occurring during snow accumulation and melting and has consequences on the evolution of local avalanche danger (e.g., Schweizer et al., 2003), hydrological response of mountainous catchments (e.g., Winstral et al., 2002), and alpine ecosystem developments (e.g., Carlson et al., 2015). At local scales, the spatial variability during snow accumulation is governed by three main processes: (i) orographic snowfall (e.g., Colle et al., 2013; Stoelinga et al., 2013), (ii) preferential deposition of falling snow (Dadic et al., 2010; Lehning et al., 2008), and (iii) wind-induced snow transport of snow on the ground during or after snowfall (e.g., Liston \& Sturm, 1998; Mott et al., 2010; Vionnet et al., 2014). Additional variability is generated by snow avalanches occurring in steep slopes (e.g., Bernhardt et al., 2012).

Orographic snowfall results from interactions between the ambient atmospheric circulation and the mountainous topography generating regions of enhanced or reduced snowfall relative to the situation in the absence of topography (Colle et al., 2013). At large scales, the maximum of snowfall tends to be found on the windward side of mountain range due to forced mechanical lifting leading to cooling of the air column and resulting in condensation and precipitation (e.g., Smith et al., 2003). At local scales, microphysical processes such as the seeder-feeder mechanism can produce local enhancement of snowfall (e.g., Choularton \& Perry, 1986; Mott et al., 2014). Snow deposition is also affected by purely dynamical interactions between falling particles and the complex airflow. Indeed, advection of falling snow particle by the ambient flow can favor a leeward shift of the snowfall maximum (Zängl, 2008). More generally, Lehning et al. (2008) introduced the concept of preferential deposition to refer to the spatially variable deposition of snowfall due to the complex near-surface flow field found in mountainous terrain. Reduced deposition velocities on the windward slope

O2017. American Geophysical Union. All Rights Reserved. 
due to higher wind speed and updraft and increased deposition velocities on the leeward side lead to preferred deposition of snow leeward of mountain ridges (e.g., Dadic et al., 2010; Mott et al., 2010). Wind-induced snow transport during or after snowfall generates additional variability of snow depth in mountainous terrain (e.g., Mott et al., 2010; Vionnet et al., 2014). Snow particles are transported in saltation close to the ground and in turbulent suspension where the distance of transport is limited by sublimation (e.g., Pomeroy \& Gray, 1995).

An open question concerns the relative importance of the different processes shaping the small-scale $(10-100 \mathrm{~m})$ spatial variability of the snowpack in alpine terrain. Progress in observations techniques over the last 15 years have made possible the detailed investigation of this spatial variability. Terrestrial and airborne laser scanners (ALS) have been used to derive high-resolution maps of snow depth (e.g., Deems et al., 2013; Prokop et al., 2008; Schirmer et al., 2011; Schön et al., 2015) and to quantify the influence of several topographic features such as slope, elevation, or wind exposure on snow accumulation. Similarly, X-band radars have been deployed in alpine terrain to investigate the variability of snowfall (Scipión et al., 2013; Mott et al., 2014). Combining snow depth data obtained by ALS and snowfall data derived from a X-band radar, Scipión et al. (2013) have shown that the spatial variability of observed snow depth on the ground is larger than the spatial variability of seasonal snowfall. They suggested that near-surface processes such as wind-induced snow transport and preferential deposition have a strong influence on snow accumulation. Mott et al. (2014) studied in details a snowfall event that occurred around Davos (Swiss Alps) and show that microphysical processes can locally influence snow deposition in combination with preferential deposition of snowfall. These two studies have illustrated the challenge of quantifying the relative influence of each process.

Numerical modeling of snow accumulation in alpine terrain can bring relevant information to discuss the influence and importance of each process. On one hand, high-resolution atmospheric model have been used to study snowfall at kilometer scale in alpine terrain and illustrate the influence of dynamical and microphysical processes on snowfall formation and variability (e.g., Colle et al., 2013; Liu et al., 2011; Zängl, 2007). On the other hand, numerical models have been developed to simulate preferential deposition and wind-induced snow transport at small scale $(10-100 \mathrm{~m})$ in alpine terrain. Lehning et al. (2008) have for example developed the Alpine 3D modeling system. It has been used to simulate snow accumulation on glacier (Dadic et al., 2010) and around typical alpine crests (Mott \& Lehning, 2010; Mott et al., 2010). These studies highlighted the large influence of preferential distribution for snow accumulation at the ridge scale (typical length: $25-150 \mathrm{~m}$ ) and suggested that saltation and turbulent suspension act at the local scale (typical length: 5-25 m). More recently, Wang and Huang (2017) combined an atmospheric model in Large Eddy Simulation (LES) mode with a Lagrangian tracking approach to simulate the deposition of falling snow. They illustrate the role of atmospheric stability on small-scale snow deposition patterns. LES simulations have also been used by Groot Zwaaftink et al. (2014) to study the temporal and spatial variability of drifting snow on small scales. Finally, other models (Liston \& Sturm, 1998; Pomeroy et al., 1997) do not include preferential deposition and only simulate drifting and blowing snow. They have been applied in complex terrain to determine the importance of saltation and turbulent suspension and the mass loss due to sublimation (Bernhardt et al., 2012; MacDonald et al., 2010). None of the models mentioned here offers the ability to account at the same time for microphysical processes occurring in complex terrain, particle-flow interactions, and wind-induced snow transport.

The objective of this paper is to propose a first numerical investigation of the different processes governing the spatial variability of snow accumulation at small scale in alpine terrain using a model that can explicitly represent these processes. It relies on the fully coupled snowpack/atmosphere model Meso-NH/Crocus (Vionnet et al., 2014). The atmospheric model Meso-NH (Lafore et al., 1998) can be used to simulate high-resolution atmospheric flow in complex terrain (Filippi et al., 2013; Vionnet et al., 2014) and precipitation in alpine terrain (Asencio \& Stein, 2006; Stein, 2004). It is coupled to the detailed snowpack model Crocus (Brun et al., 1992; Vionnet et al., 2012), and a specific module handles wind-induced snow transport (Vionnet et al., 2014). The model has previously been applied to study blowing snow events without concurrent snowfall (Vionnet et al., 2014). In this study, we use the model to simulate and analyze snow accumulation and redistribution during a snowfall event in February 2011 in the Grandes Rousses range (French Alps). Our paper is organized as follows. Section 2 describes the study area and the snowfall event. Then, section 3 presents the specific configuration of Meso-NH/Crocus used here and the experimental design. Results from model simulations are then presented and discussed in section 4. Finally, section 5 summarizes the findings and mentions future works. 

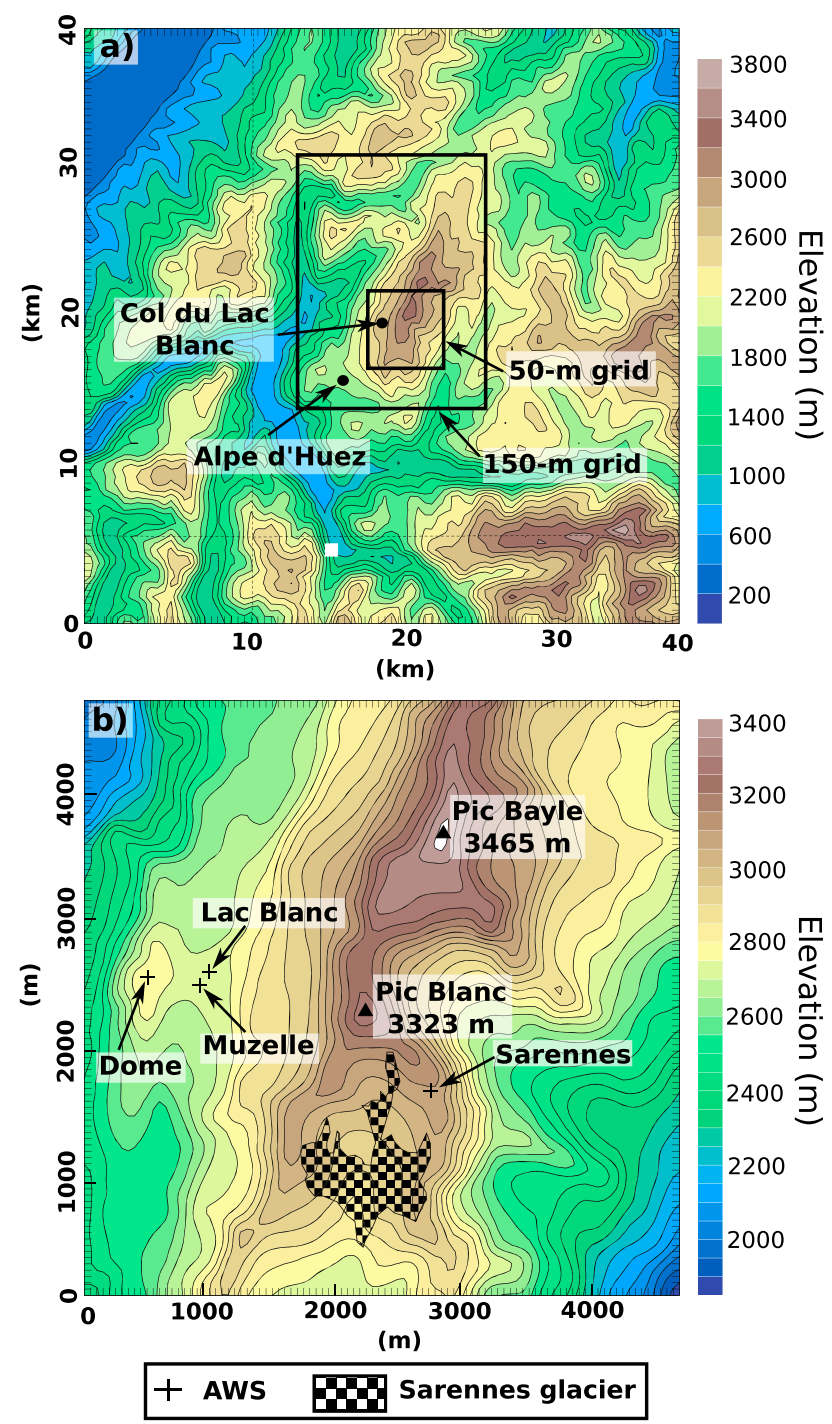

Figure 1. The elevation contours ( $m$ asl) for (a) the $450 \mathrm{~m}$ grid and (b) the $50 \mathrm{~m}$ grid. Location of surface stations (defined in Table 1) is also shown in map (Figure 1b). Black isolines correspond to $\Delta z=200 \mathrm{~m}$ in Figure $1 \mathrm{a}$ and $50 \mathrm{~m}$ in Figure $1 \mathrm{~b}$.

\section{Site Description and Case Study}

The study area is the southern part of the Grandes Rousses mountain range in the French Alps (Figure 1). It covers an area of $4.8 \times 4.8 \mathrm{~km}^{2}$ with an elevation ranging from 1,950 to $3,465 \mathrm{~m}$ above sea level (asl). This region includes typical topographic features encountered in alpine terrain: small glacier basin (Glacier de Sarennes, $0.4 \mathrm{~km}^{2}$ ), steep slopes, ridges, and peaks (Pic Blanc and Pic Bayle). Strong interactions between the atmospheric flow and the topography are therefore expected. The investigation area is equipped with four permanent automatic weather stations (AWS) (Table 1). Three of them are located around the experimental site of Col du Lac Blanc (2,720 $\mathrm{m}$ asl), a large north-south oriented pass on the western side of the Grandes Rousses range (Figure 1). This site has been established for more than 25 years as an investigation area for blowing and drifting snow in alpine terrain (e.g., Durand et al., 2001; Guyomarc'h \& Mérindol, 1998; Naaim-Bouvet et al., 2010, 2014; Vionnet et al., 2013). Specific measurements concerning blowing snow include a vertical profile of blowing snow fluxes using three Snow Particle Counters (SPC) (Sato et al., 1993).

As a case study, we selected a snowfall event that occurred on 14 and 15 February 2011. Observers present at Col du Lac Blanc those days reported that 10 to $15 \mathrm{~cm}$ of fresh snow accumulated during this event with a wind blowing continuously from the south (Figure 2, top). Its intensity measured at $5 \mathrm{~m}$ above the snow surface at Lac Blanc AWS started increasing at 2 p.m. on 14 February to reach a maximum of $13.1 \mathrm{~m} \mathrm{~s}^{-1}$ (maximal gust of $18.2 \mathrm{~m} \mathrm{~s}^{-1}$ ) at 9 a.m. on 15 February (Figure 2, middle). Such wind speeds were sufficient to generate redistribution of the accumulated snowfall as confirmed by the blowing snow fluxes measured at Col du Lac Blanc (Figure 2, bottom). Wind-induced snow transport occurred from 3:30 p.m. on 14 February to 2 p.m. on 15 February with a succession of snow transport with and without snowfall. Note that all the snow redistributed by the wind during this event around Col du Lac Blanc came from the snowfall since the top layer of initial snowpack was nonerodible with a density ranging from 350 to $430 \mathrm{~kg} \mathrm{~m}^{-3}$. The last significant snowfall over the Grandes Rousses ranges had occurred more than a month earlier on 11 January 2011. Finally, during our case study, the relative humidity with respect to ice measured at Sarennes AWS remained above $96 \%$. Therefore, the contribution of blowing snow sublimation for this event is expected to be insignificant (Groot Zwaaftink et al., 2011).

The precipitation gauge installed at Col du Lac Blanc is strongly influenced by wind undercatch during blowing snow events with concurrent snowfall. Therefore, to get an estimation of snowfall amount at Col du Lac Blanc during our case study, we used the method proposed by Naaim-Bouvet et al. (2014). This method relies on a detailed analysis of the mass fluxes measured by the highest SPC located at $3.8 \mathrm{~m}$ above the snow surface. The occurrence of snowfall

Table 1

List of Weather Stations and Recorded Meteorological Variables

\begin{tabular}{lcccccc}
\hline Name & Latitude $\left({ }^{\circ} \mathrm{N}\right)$ & Longitude $\left({ }^{\circ} \mathrm{E}\right)$ & Elevation $(\mathrm{m})$ & Variables & Frequency $(\mathrm{min})$ & Height $(\mathrm{m})$ \\
\hline Dome & $45^{\circ} 07^{\prime} 40.44^{\prime \prime}$ & $06^{\circ} 06^{\prime} 21.24^{\prime \prime}$ & 2,807 & U, D, T & 15 & 4 \\
Muzelle & $45^{\circ} 07^{\prime} 38.28^{\prime \prime}$ & $06^{\circ} 06^{\prime} 39.96^{\prime \prime}$ & 2,722 & U, D, T & 15 & 5 \\
Lac Blanc & $45^{\circ} 07^{\prime} 41.88^{\prime \prime}$ & $06^{\circ} 06^{\prime} 43.56^{\prime \prime}$ & 2,709 & U, D, T & 15 & 5 \\
Sarennes & $45^{\circ} 07^{\prime} 09.96^{\prime \prime}$ & $06^{\circ} 08^{\prime} 01.32^{\prime \prime}$ & 3,070 & U, D, T, RH & 30 & 5 \\
\hline
\end{tabular}

Note. (U: wind speed; D: wind direction; T: air temperature; $\mathrm{RH}$ : relative humidity). Height refers to the height of the instruments above the snow surface. 

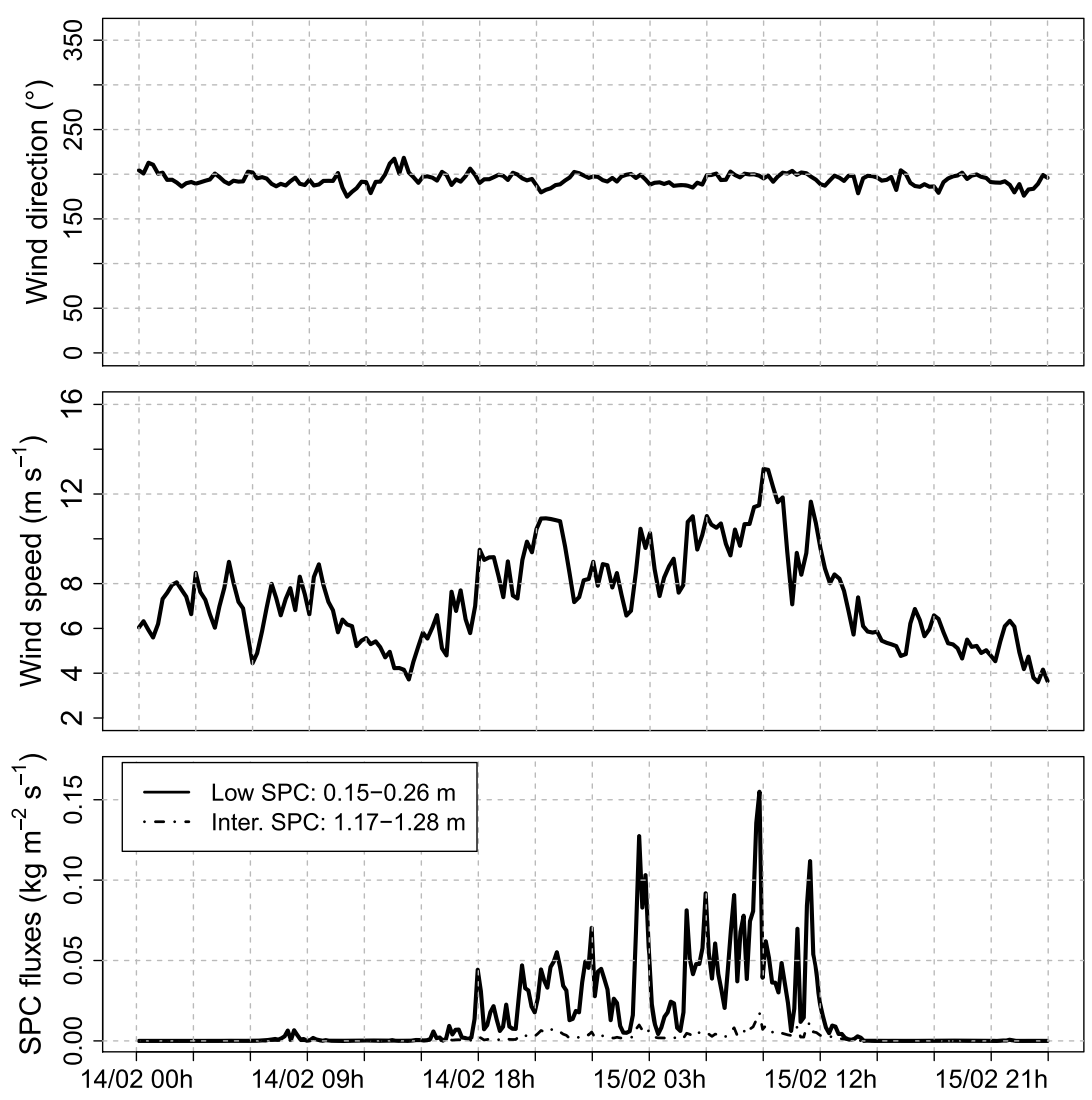

Figure 2. Times series of meteorological variables measured at Col du Lac Blanc during the case study: $5 \mathrm{~m}$ wind direction (top) and speed (middle) and snow particles fluxes measured by SPC at two levels above the surface (bottom).

is first identified by analyzing the dependence of snow flux and mean diameter according to wind speed. The amount of solid precipitation is then derived using a settling velocity for each class of diameter measured by the SPC. A first estimation of snowfall amount (Method 1) is obtained assuming that all the snow particles detected by the highest SPC during our case study are made of falling snow particles. This provides an upper value for the total amount of solid precipitation which reaches $12.2 \mathrm{~mm}$ w.e. (water equivalent) for this event. A second estimation (Method 2) accounts for the contribution of blown snow particles on the mass flux measured by the highest SPC using the power law relationship between the mass flux and the wind speed found when blowing snow occurs with concurrent snowfall (Naaim-Bouvet et al., 2014). This contribution is then removed from the total snow flux. A total of $8.7 \mathrm{~mm}$ w.e. is found using this method. These precipitation amounts are in agreement with the estimation of 10 to $15 \mathrm{~cm}$ of fresh snow reported by scientists present at the site during this event. The main uncertainty associated with the method lies in the estimation of the mean diameter for falling snow as discussed in Naaim-Bouvet et al. (2014).

\section{Model Description and Experimental Design}

\subsection{Coupled Snowpack/Atmosphere Model}

The coupled model consists of two components: the atmospheric model Meso-NH (Lafore et al., 1998) and the detailed snowpack model Crocus (Brun et al., 1992; Vionnet et al., 2012). Crocus is coupled to Meso-NH through the externalized surface module SURFEX (Masson et al., 2013) which handles energy and mass exchange between the atmosphere and the surface. Additionally, dedicated routines allow the coupled model to simulate wind-induced snow transport (Vionnet et al., 2014).

Meso-NH is a nonhydrostatic atmospheric model which is applicable at horizontal resolution ranging from meters to several tens of kilometers and used here in a LES configuration (Aumond et al., 2013; Bergot et al., 2015). Large-scale information is provided to the LES resolution using techniques of grid nesting (Stein et al., 2000). We only mention below the relevant settings of the model for our application. Momentum is advected 
with the WENO (Weighted Nonoscillatory) (Shu, 1998) scheme at third order, whereas scalar and meteorological variables are advected with the PPM (Piecewise Parabolic Method) scheme (Colella \& Woodward, 1984). The model uses a full three-dimensional turbulent scheme based on a 1.5-order turbulence closure (Cuxart et al., 2000). In LES configuration, the model uses the mixing length of Deardorff (1972), equal to the grid size of the model limited by the thermal stability. The microphysical scheme for mixed phase clouds of Pinty and Jabouille (1998) (referred to as ICE3) simulates cloud development and resulting precipitation (rainfall and snowfall). It makes the distinction between three types of ice species characterized by different shape, size, and degree of riming: primary ice crystals, snow/aggregates, and graupel. The terminal fall speed of primary ice crystal is negligible compared to that of snow/aggregates and graupel which form snowfall accumulating at the surface. Using the ICE3 microphysical scheme, Lascaux et al. (2006) investigated intense orographic precipitation and associated microphysical processes during three MAP (Mesoscale Alpine Program) cases.

At the bottom of the atmosphere, Crocus represents the detailed layering of the snowpack at each grid cell of the simulation domain. It simulates within each layer the evolution of snow properties (density, temperature, grain type and size, ... ) as a function of the near-surface meteorological variables simultaneously computed by Meso-NH. Snowfall from the atmospheric model is incorporated into the snowpack. The characteristics of new snow (density, dendricity, and sphericity) depend on the near-surface wind speed and air temperature (Vionnet et al., 2012, 2013). At the bottom of the snowpack, Crocus is fully coupled to the soil component of the land surface scheme ISBA (Boone et al., 2000; Noilhan \& Planton, 1989) through an explicit scheme.

An option allows Meso-NH/Crocus to simulate wind-induced snow redistribution (Vionnet et al., 2014). The model makes the distinction between snow transport in saltation and turbulent suspension. Snow transport occurs when the near-surface wind speed simulated by Meso-NH exceeds the threshold wind speed given by Crocus as a function of snow grain type at the surface (Guyomarc'h \& Mérindol, 1998). Therefore, new snow resulting from snowfall simulated by Meso-NH (total contribution of snow aggregates and graupel) can be redistributed by the blowing snow scheme if the wind speed is sufficient. In the atmosphere, blown snow particles are represented by a double moment scheme to capture the spatial and temporal evolution of the particle size distribution. For this study, blowing snow sublimation is not activated as mentioned in section 2. The surface boundary layer (SBL) scheme implemented in SURFEX (Masson \& Seity, 2009) increases the vertical resolution close to the snow surface to reproduce strong gradients of blowing snow concentration and compute mass exchanges between the snowpack and the atmosphere. Overall, the mass balance of the snowpack includes the contribution of snowfall, surface sublimation, and snow transport in saltation and turbulent suspension. The model topography is constant during the simulation and does not change as function of snow depth change due to snowfall or wind-induced redistribution. A complete description of the blowing snow scheme can be found in Vionnet et al. (2014).

\subsection{Experimental Design}

\subsubsection{Atmospheric Model}

Meso-NH is configured to simulate the evolution of weather conditions over the southern part of Grandes Rousses range during our case study with three nested grid domains (Figure 1). The grid size of the three domains are 450, 150, and $50 \mathrm{~m}$, respectively. Region 1 covers several mountains ranges around the Grandes Rousses, while Region 3 encloses the experimental site of Col du Lac Blanc and the southern ridges of the Grandes Rousses range. Region 2 simulates the weather processes at the scale of the Grandes Rousses range. Details of the simulation domains are listed in Table 2. Topography for the $450 \mathrm{~m}$ grid was obtained using the $250 \mathrm{~m}$ digital elevation model of the French Geographical Institute (IGN). The $150 \mathrm{~m}$ resolution and the $50 \mathrm{~m}$ terrains were extracted from a $45 \mathrm{~m}$ data set produced by IGN over the Grandes Rousses range. Over the three domains, Meso-NH uses a stretched vertical grid of 70 layers with 20 layers in the lowest $200 \mathrm{~m}$ of the atmosphere to reproduce the vertical structure of the boundary layer. The SBL scheme increases the vertical resolution close to the surface by adding five atmospheric layers (lowest level: $15 \mathrm{~cm}$ above the snowpack) between the surface and the first level of Meso- $\mathrm{NH}$. The surface aerodynamic roughness is set at $0.003 \mathrm{~m}$ based on measurements made at Col du Lac Blanc for southern winds (Vionnet, 2012).

To obtain realistic initial and boundary conditions, analysis from the French operational meteorological model AROME (Seity et al., 2011) was used to force Meso-NH simulations at the lateral boundaries of the coarsest resolution $(450 \mathrm{~m}$ ) grid (Figure 3). AROME analysis is given at $3 \mathrm{~h}$ intervals with $2.5 \mathrm{~km}$ horizontal spacing and 41 vertical levels to be linearly interpolated in time by Meso- $\mathrm{NH}$. Simulations at the $450 \mathrm{~m}$ resolution continued for $24 \mathrm{~h}$ starting at 12 UTC 14 February. Output every 15 min was used to provide initial and boundary 
Table 2

Nested Grid Configuration With Dimensions

\begin{tabular}{llccc}
\hline Region & Grid size & Domain $(\mathrm{km})$ & $\Delta \mathrm{x}, \Delta y$ & Time step \\
\hline R1 & $90 \times 90 \times 70$ & $40 \times 40$ & $450 \mathrm{~m}$ & $4 \mathrm{~s}$ \\
R2 & $80 \times 108 \times 70$ & $12 \times 16.2$ & $150 \mathrm{~m}$ & $2.5 \mathrm{~s}$ \\
R3 & $96 \times 96 \times 70$ & $4.8 \times 4.8$ & $50 \mathrm{~m}$ & $1.25 \mathrm{~s}$ \\
\hline
\end{tabular}

condition files for the $150 \mathrm{~m}$ nested grid. The $150 \mathrm{~m}$ and $50 \mathrm{~m}$ simulations run simultaneously in one-way nesting from 15 UTC 14 February to 12 UTC 15 February. The $150 \mathrm{~m}$ simulation provides lateral boundary conditions updated at each time step for the $50 \mathrm{~m}$ simulation. Such procedures of grid nesting have previously shown promising results in complex terrain (Chow et al., 2006; Michioka \& Chow, 2008; Weigel et al., 2006).

We performed two sets of $150 \mathrm{~m}$ and $50 \mathrm{~m}$ simulations of our case study: one without wind-induced snow transport (CTRL) and one with snow transport (TRANS). Both simulations receive the same lateral boundary conditions from the $450 \mathrm{~m}$ simulation.

\subsubsection{Land Surface Model}

Soil and surface properties (sand and clay fraction, vegetation types, ... ) are obtained from ECOCLIMAP $1 \mathrm{~km}$ resolution global data (Masson et al., 2003) and from the FAO $10 \mathrm{~km}$ resolution database for soil texture. The data are further interpolated to the $450 \mathrm{~m}, 150 \mathrm{~m}$, and $50 \mathrm{~m}$ resolution grids. Simulations over the three grids were performed using a version of ISBA featuring a multilayer explicit soil mass and heat transfer (Boone et al., 2000). Five numerical soil layers are used with increasing vertical resolution near the surface. For the snowpack, two distinct configurations of Crocus are considered as a function of the horizontal resolution of the grid. They differ in terms of model complexity and initialization procedures. The $450 \mathrm{~m}$ resolution grid used a simplified version of Crocus with a maximal number of layers in the snowpack set to 3 . Snowpack and soil prognostic variables on the $450 \mathrm{~m}$ resolution grid are initialized from AROME analysis at $2.5 \mathrm{~km}$ horizontal spacing.

The $150 \mathrm{~m}$ and $50 \mathrm{~m}$ resolution grids require a more detailed representation of the snowpack since windinduced snow transport is simulated over these grids. Therefore, we use a version of Crocus allowing a maximal number of 20 layers to represent the detailed layering of the snowpack. Simulations CRTL and TRANS use the same snowpack and soil initial conditions over the $150 \mathrm{~m}$ and $50 \mathrm{~m}$ resolution grids. They were obtained from distributed simulations using SURFEX/Crocus in off-line mode. Following the method described in Vionnet et al. (2012), distributed simulations at $150 \mathrm{~m}$ and $50 \mathrm{~m}$ resolutions started from 1 August 2010 over snow-free domains and lasted until the beginning of the coupled simulations (15 UTC 14 February 2011). The meteorological forcing is based on the hourly output of the SAFRAN meteorological analysis system (Durand et al., 1993) for the Grandes Rousses range. It includes air temperature and humidity, wind speed, precipitation and downward longwave and shortwave direct and diffuse incident radiation for six different aspects $(\mathrm{N}, \mathrm{E}, \mathrm{SE}, \mathrm{S}, \mathrm{SW}, \mathrm{W})$ at $300 \mathrm{~m}$ elevation intervals. Meteorological forcing was interpolated at each grid point as a function of its elevation, local slope, and aspect. The off-line simulations do not include wind-induced snow transport.

\section{Results and Discussions}

\subsection{Model Evaluation}

\subsubsection{Wind Field and Temperature}

The instantaneous flow field simulated near the surface over the $50 \mathrm{~m}$ grid is shown in Figure 4 for a date of the morning of 15 February when snow transport intensity was maximal at Col du Lac Blanc (Figure 2). As shown in Vionnet et al. (2014), the near-surface wind field simulated by Meso-NH is strongly controlled

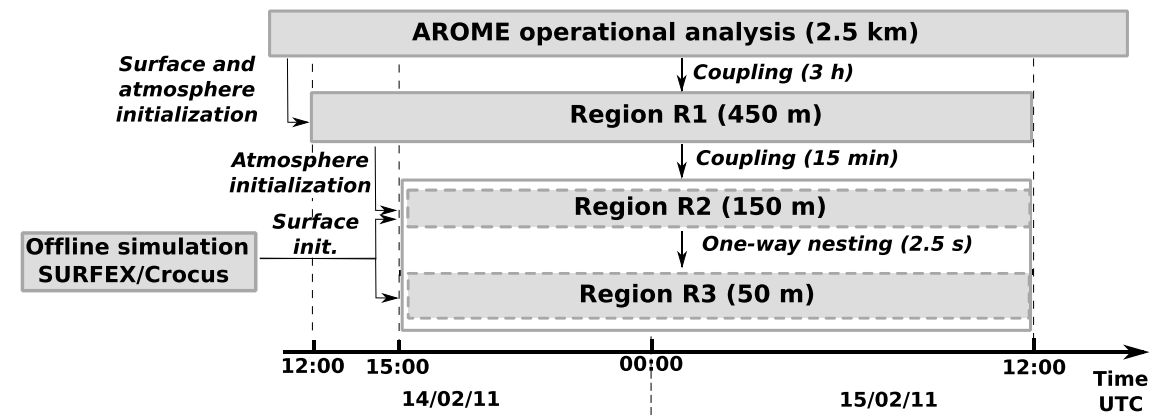

Figure 3. Overview of the strategy for the initialization of atmosphere and surface for our case study around Col du Lac Blanc. The location of the different simulation regions is shown in Figure 1. Time is given in UTC. 


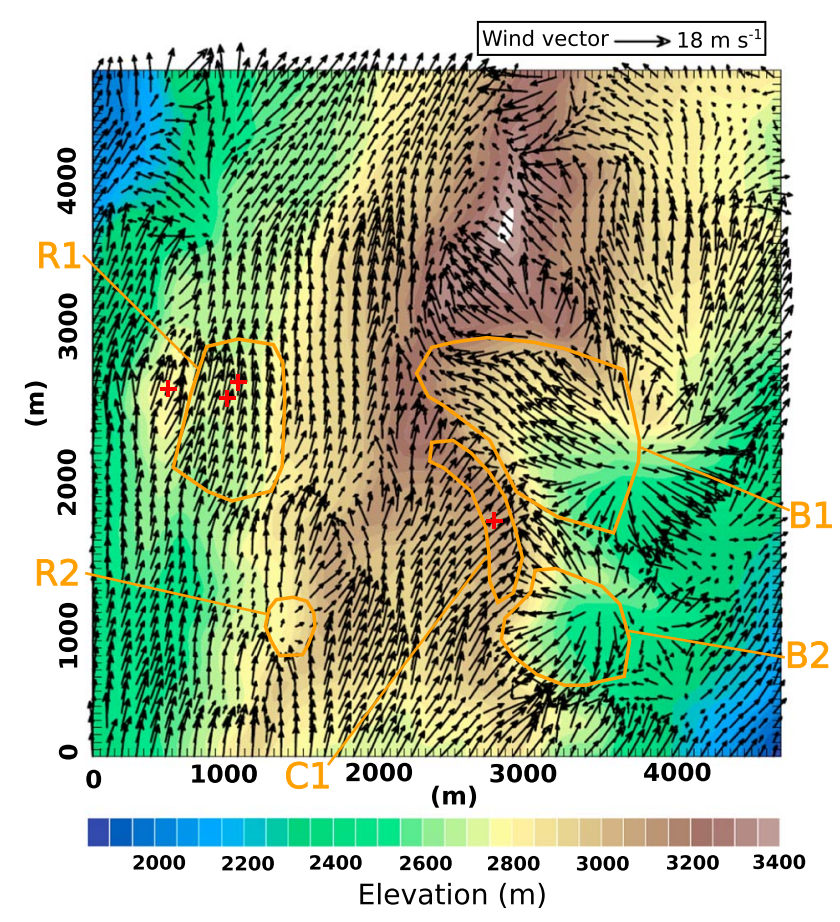

Figure 4. Instantaneous wind field at first atmospheric level (1.8-3 m above the surface) on 15 February 2011 8:30 over the 50 m grid. Arrows indicate wind direction and intensity, while colors indicate elevation. Properties of wind field in areas with orange contours are discussed in the text. Red crosses indicate the location of AWS listed in Table 1. by the orography. The model reproduces the main features of atmospheric flow in complex terrain (e.g., Raderschall et al., 2008). The local topography around Col du Lac Blanc creates for example a channeling of the atmospheric flow characterized by an increase in wind speed and a wind direction aligned with the main axis of the pass (region R1 in Figure 4). The presence of crests (crest $\mathrm{C} 1$ in Figure 4) generates cross-ridge flow and associated crest speedup. On the leeward side of some crests, recirculation zones characterized by low wind speed and changing wind direction can locally formed (e.g., region R2 in Figure 4). Finally, two basins lying on the eastern slopes of the Grandes Rousses range (basins B1 and B2 in Figure 4) exhibit upslope flow that can be locally opposite to the main southern synoptic flow observed above the crest.

Four automatic weather stations located in the $50 \mathrm{~m}$ domain (Table 1 and Figure 1) allow us to evaluate the performance of the numerical simulations in reproducing the near-surface atmospheric conditions. All results are from the $50 \mathrm{~m}$ resolution grid since the spatial distribution of snow accumulation will be considered at this resolution (section 4.2). Model results are taken at lowest atmospheric level $(1.8-3 \mathrm{~m})$, and simulated wind speeds are corrected to the sensor height (Table 1) using a logarithmic wind profile and a roughness length of $0.003 \mathrm{~m}$ (derived from measurements made at Col du Lac Blanc for southern winds (Vionnet, 2012)). Figure 5 shows the evolution of near-surface air temperature and wind direction and speed at three stations, while Table 3 gives the root-mean-square errors (RMSE) and mean errors (Bias) between the Meso-NH simulation and surface observation at four sites. Meso-NH captures well the decrease in air temperature during our case study despite a slight negative bias (Table 3). It also reproduces the differences of temperature between stations at different elevations meaning that the temperature lapse rate and associated atmospheric stability is correctly captured by the model.

Results for wind speed and direction are more contrasted. Around Col du Lac Blanc, at stations Dome and Muzelle, wind direction remains from south during the whole event in the observations and in the simulation leading to low errors in wind direction (RMSE lower than $20^{\circ}$ ) when compared with the results of other typical simulations over complex terrain (e.g., Michioka \& Chow, 2008). This is mainly due to the strong control exerted by the local topography on atmospheric flow around Col du Lac Blanc. Meso-NH captures also the increase in wind speed from 3 p.m. to 9 p.m. on 14 February at AWS Dome and Muzelle but tends to overestimate the wind speed at these two stations from 9 p.m. on 14 February to 9 a.m. on 15 February leading to an overall positive bias of wind speed at these two stations. The wind channeling through Col du Lac Blanc is associated with a wind speedup (region R1, Figure 4) with an observed mean wind speed $19 \%$ higher at AWS Muzelle than at AWS Dome (Table 4). The simulated wind speedup between these two stations agrees with the observation and reaches $22 \%$. A similar agreement is found for the wind speedup at AWS Lac Blanc compared to AWS Dome (Table 4). Results are more contrasted at AWS Sarennes in the upper basin of the Sarennes glacier (Figure 1) where the model overestimates wind speed and presents a bias in wind direction. This station is located at $120 \mathrm{~m}$ of the crest line. In this region, Meso-NH simulates an intense crest speedup associated with the partial smoothing of the crest in the model. Mott et al. (2010) found similar effects using the atmospheric model ARPS in alpine terrain.

\subsubsection{Mass Fluxes: Snowfall and Blowing Snow Fluxes at Col du Lac Blanc}

The amount of snowfall during this event has been derived from the SPC data using the method of Naaim-Bouvet et al. (2014) as described in section 2. Figure 6 compares the time series of cumulated solid precipitation derived from the SPC and simulated by Meso-NH in simulation CTRL. Results are the same for simulation TRANS. Solid precipitation in Meso-NH is simulated by the cloud microphysical scheme and is made of two types of solid hydrometeors: (i) snow aggregates and (ii) graupel. Snow aggregates correspond to dry to lightly rimed large ice crystals or snowflakes (assemblage of ice crystals), whereas graupel correspond to more heavily rimed particles formed by raindrop contact freezing or heavy riming of snowflakes. At Col du Lac Blanc, Meso-NH simulates a total accumulation of $20.4 \mathrm{~mm}$ w.e. during our case study: $78 \%$ are made 

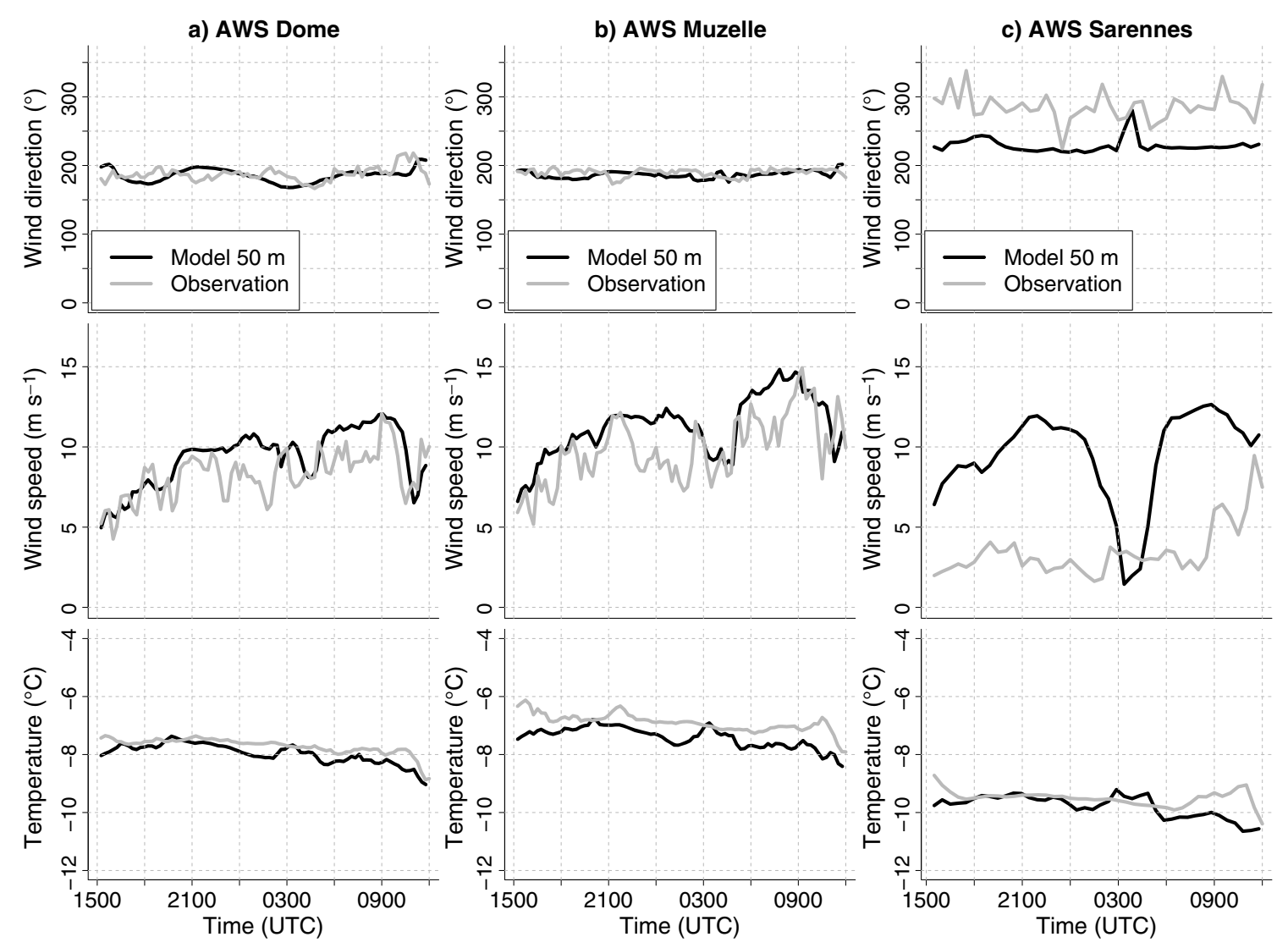

Figure 5. Times series of observed and simulated meteorological conditions: wind direction (top) and speed (middle) and air temperature (bottom) at three automatic weather stations. The location of each station is given in Figure 1.

of snow aggregates $(15.9 \mathrm{~mm})$ and $22 \%$ of graupel $(4.5 \mathrm{~mm})$. The model tends to overestimate total solid precipitation when compared to the two estimations derived from SPC (12.2 and $8.7 \mathrm{~mm}$ using Methods 1 and 2 , respectively). The overestimation mainly results from an overestimation of solid precipitation at the beginning of our case study.

SPC data have been also used to evaluate blowing snow fluxes simulated at Col du Lac Blanc in simulation TRANS. Measured vertical profiles of snow fluxes have been divided into five categories of $2 \mathrm{~m}$ wind speed (width: $1 \mathrm{~m} \mathrm{~s}^{-1}$ ) covering the range $8-12 \mathrm{~m} \mathrm{~s}^{-1}$ as in Vionnet et al. (2014). The same classification has been applied to simulated data, and averaged simulated profiles have been calculated for each category. Figure 7 shows the comparison between observed and simulated profiles for each category of wind speed. As mentioned earlier, fluxes measured by SPC include the contribution of falling snow particles. This contribution is

Table 3

Error Statistics (Bias and RMSE) for Wind Speed, $U$, Wind Direction, $\Phi$, and Temperature, $\theta$, From the Comparison Between Simulation at $50 \mathrm{~m}$ Grid Spacing and Measurements at Four AWS (Table 1)

\begin{tabular}{|c|c|c|c|c|c|c|}
\hline \multirow[b]{2}{*}{ Station } & \multicolumn{2}{|c|}{$\Phi(\mathrm{deg})$} & \multicolumn{2}{|c|}{$U\left(\mathrm{~m} \mathrm{~s}^{-1}\right)$} & \multicolumn{2}{|c|}{$\theta(\mathrm{K})$} \\
\hline & RMSE & Bias & RMSE & Bias & RMSE & Bias \\
\hline Lac Blanc & 15.3 & -13.4 & 1.8 & 1.1 & 0.4 & -0.2 \\
\hline Muzelle & 8.1 & -2.9 & 2.1 & 1.5 & 0.6 & -0.5 \\
\hline Dome & 13.2 & -1.9 & 1.8 & 1.1 & 0.3 & -0.3 \\
\hline Sarennes & 60.7 & -56.8 & 6.7 & 6.0 & 0.5 & -0.3 \\
\hline
\end{tabular}

Note. Modeled wind speed was scaled to measurement height of AWS assuming a logarithmic wind profile. particularly observed with the highest SPC located between 3.2 and $3.5 \mathrm{~m}$ above the snow surface for wind speed from 8 to $9 \mathrm{~m} \mathrm{~s}^{-1}$. In this case, the vertical profile of snow flux differs from the power law typically found when blowing snow occurs without concurrent snowfall (e.g., Naaim-Bouvet et al., 2010; Trouvilliez et al., 2015). Therefore, the contribution of falling solid hydrometeors (snow and graupel) has been also calculated for simulated fluxes (blue lines in Figure 7). It uses the concentration of snow and graupel simulated at the first atmospheric level of Meso-NH and assumes a constant concentration for all levels in the SBL scheme (between 0.15 and $3.5 \mathrm{~m}$ ).

Figure 7 reveals that fluxes of solid hydrometeors need to be taken into account to reproduce the vertical profile and typical ranges of snow fluxes observed between 1 and $3.5 \mathrm{~m}$. Below $1 \mathrm{~m}$, the contribution of solid hydrometeors to the total simulated snow flux is reduced since most of the transported snow mass consists of blown snow particles. In this region, Meso-NH/Crocus 
Table 4

Simulated and Observed Ratio Between Mean Speed at AWS Muzelle and Lac Blanc Located at Col du Lac Blanc and Mean Wind Speed at AWS Dome Located Above Col du Lac Blanc

\begin{tabular}{lcc}
\hline Station & Observed ratio & Simulated ratio \\
\hline Lac Blanc & 1.09 & 1.10 \\
Muzelle & 1.19 & 1.22 \\
\hline
\end{tabular}

tends to overestimate the snow mass flux. The relative importance of this overestimation decreases with increasing with speed. Overall, the model overestimates the vertically integrated mass flux between 0.3 and $3 \mathrm{~m}$ (Figure 7) for each wind speed category. The overestimation is larger when accounting for the contribution of solid hydrometeors to the total mass flux. In this configuration, the relative bias between model and observations decreases when the wind speed increases (from 2.5 at $8 \mathrm{~m} \mathrm{~s}^{-1}$ to 1.6 at $12 \mathrm{~m} \mathrm{~s}^{-1}$ ).

This overestimation of the mass flux can be associated with an overestimation of the snow concentration in the saltation layer that acts as a lower boundary condition for the suspension layer. The snow transport scheme in Meso-NH/Crocus uses for the saltation layer the parameterization of Sørensen (2004) adapted to snow (Vionnet et al., 2014). This parameterization has not initially been developed for fresh snow and may lead to inaccurate estimation of snow fluxes in the saltation layer. A detailed analysis also reveals that the simulated $2 \mathrm{~m}$ threshold wind speed ranges between 5 and $7 \mathrm{~m} \mathrm{~s}^{-1}$ during our case study, whereas the lower SPC gives an estimated threshold wind speed around $7 \mathrm{~m} \mathrm{~s}^{-1}$. This underestimation favors an overestimation of the mass flux in the saltation layer, especially for the wind speed categories just above the threshold wind speed. For instance, at $8 \mathrm{~m} \mathrm{~s}^{-1}$, the parameterization of Sørensen (2004) gives transport rates of 0.080 and $0.032 \mathrm{~kg} \mathrm{~m}^{-1} \mathrm{~s}^{-1}$ for a $2 \mathrm{~m}$ threshold wind speed of 7 and $5 \mathrm{~m} \mathrm{~s}^{-1}$, respectively. Therefore, an accurate estimation of fresh snow properties is required to determine the evolution of the threshold wind speed during a blowing snow event with concurrent snowfall (Vionnet et al., 2013). In particular, in our case study, the degree of riming of falling snow (see section 4.2) may influence the threshold wind speed for snow transport since it strongly influences falling snow properties (Ishizaka et al., 2016).

\subsection{Spatial Variability of Snow Accumulation}

Meso-NH/Crocus explicitly simulates the microphysical processes leading to snowfall, the advection and the sedimentation of solid hydrometeors, and the transport of deposited fresh snow (made of snow aggregates and graupel) if the wind speed is sufficient. In the following, we detail and analyze the different processes leading to the spatial variability of the simulated snow accumulation and discuss their relative importance.

\subsubsection{Spatial Distribution of Solid Precipitation}

Figure 8a shows the total amount of solid precipitation simulated by Meso-NH in simulation CTRL at $50 \mathrm{~m}$ grid spacing from 3 p.m. on 14 February to 12 a.m. on 15 February. The solid precipitation is the sum of the contributions of two solid hydrometeors: snow aggregates (Figure 8b) and graupel (Figure 8c). The amount of

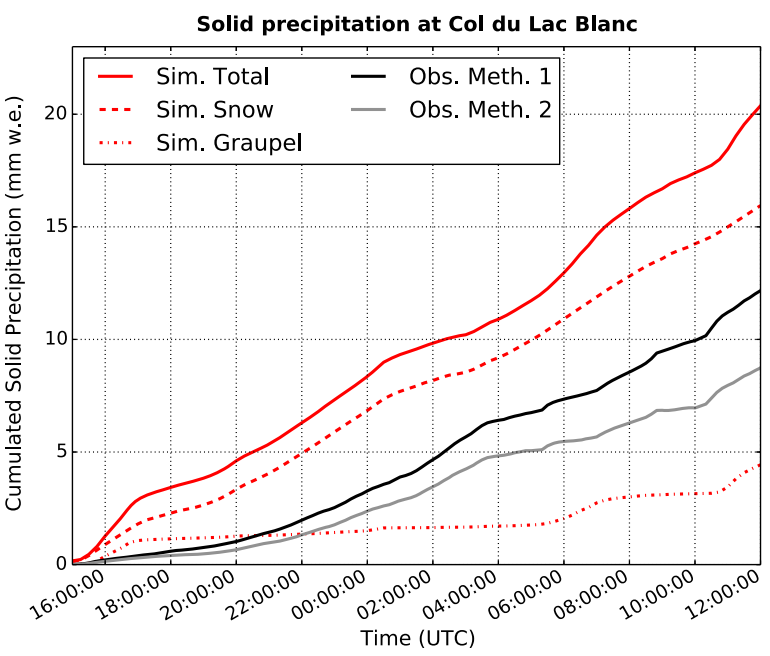

Figure 6. Time series of cumulated solid precipitation at Col du Lac Blanc from 14 February 15:00 to 15 February 12:00 estimated from SPC data (Methods 1 and 2 described in section 2) and simulated by Meso-NH (simulation CTRL): total solid precipitation and individual contribution from snow aggregates and graupel. solid precipitation exhibits a contrasted spatial pattern associated with large differences between the accumulation of these two hydrometeors. The amount of snow aggregates mainly increases with elevation up to $3000 \mathrm{~m}$ and nearly remains constant above this altitude (Figure 9). Up to $2,500 \mathrm{~m}$, solid precipitation mainly accumulates as snow aggregates so that the total precipitation amount increases with elevation with a low spatial variability per elevation band (Figure 9). Above 2,500 m, the contribution of graupel increases and graupel becomes the main source of solid precipitation above $3200 \mathrm{~m}$. The accumulation of graupel is associated with a strong spatial variability as illustrated by the size of the boxes for each elevation band in Figure 9. Maxima of graupel accumulation are found along the crest lying on the eastern side of the Sarennes AWS, in a large bowl on the northeastern side of the Pic Blanc and above Pic Bayle (Figure $8 \mathrm{c}$ ). They correspond to the maxima of solid precipitation (above $50 \mathrm{~mm}$ ) in the region.

Overall, the simulated amount of total solid precipitation increases on average with elevation up to 3,200 m (Figure 9). Above this elevation (7\% of the simulation domain), it remains nearly constant. Similar trends have been identified in studies focusing on snow distribution as a function of elevation in mountainous terrain (Grünewald et al., 2014; Kirchner et al., 2014). The authors found an increase of snow depth with elevation until 

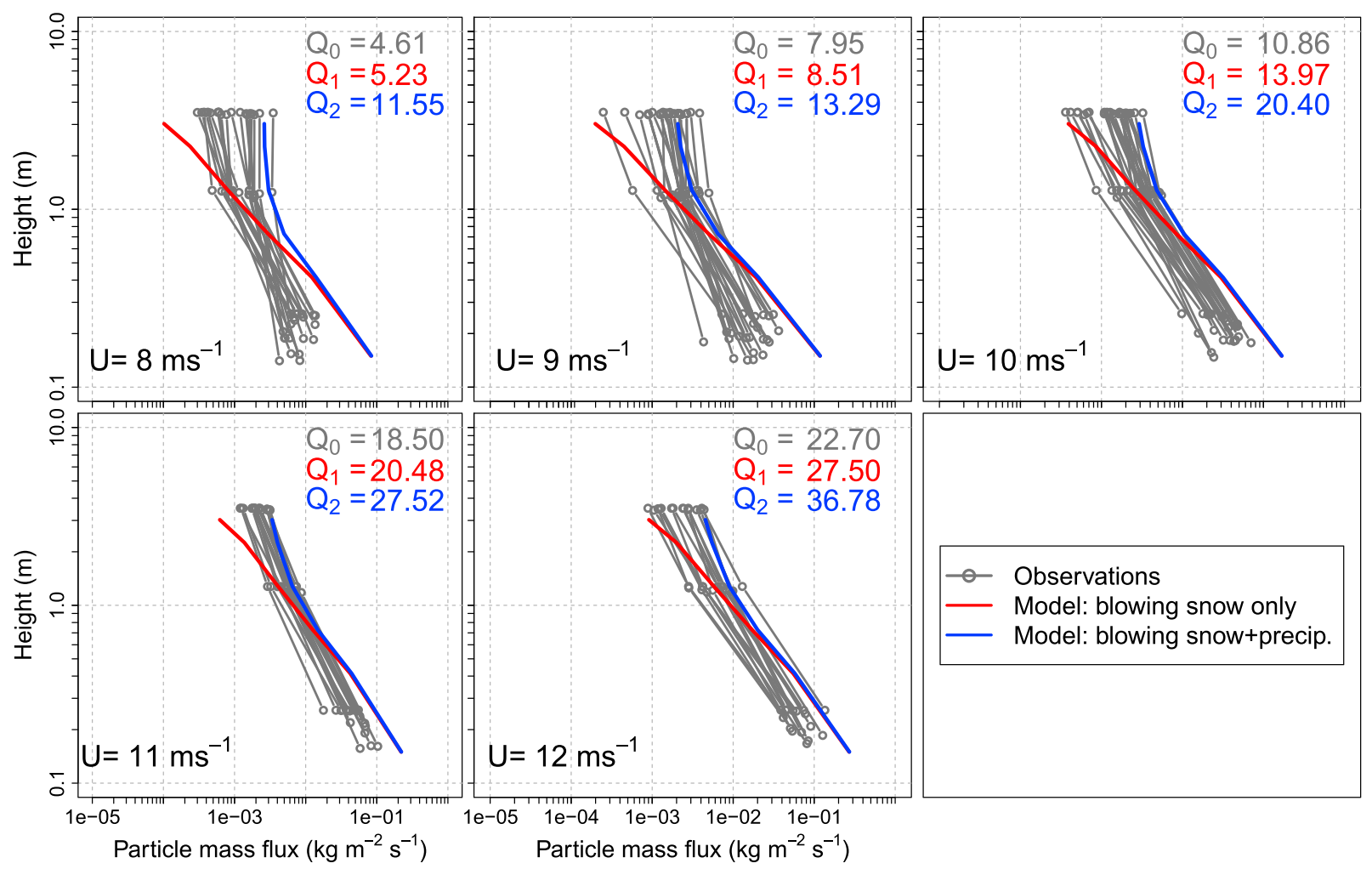

Figure 7. Vertical profile of blowing snow fluxes simulated by Meso-NH/Crocus (simulation TRANS) and measured with SPC for five categories of $2 \mathrm{~m}$ wind speed at Col du Lac Blanc. The blue curves include the contribution in the simulation of precipitating snow and graupel to the total mass flux. For a given category, $Q$ refers to the vertically integrated rate of suspended snow $\left(10^{-3} \mathrm{~kg} \mathrm{~m}^{-1} \mathrm{~s}^{-1}\right)$ between 0.3 and $3 \mathrm{~m}$ above the snow surface measured with the SPC $\left(Q_{0}\right.$, averaged value), simulated in run TRANS without $\left(Q_{1}\right)$ and with $\left(Q_{2}\right)$ the contribution of precipitating snow and graupel.

a maximum value followed by a more or less definitive decrease. They suggest that the vertical profile of snowfall may partially explain this shape of the vertical distribution of snow depth with elevation. Model results from our case study confirm the reliability of this assumption. However, further investigation is required to know if this trend is found at the seasonal scale and how it depends on synoptic meteorological conditions.

a) Total

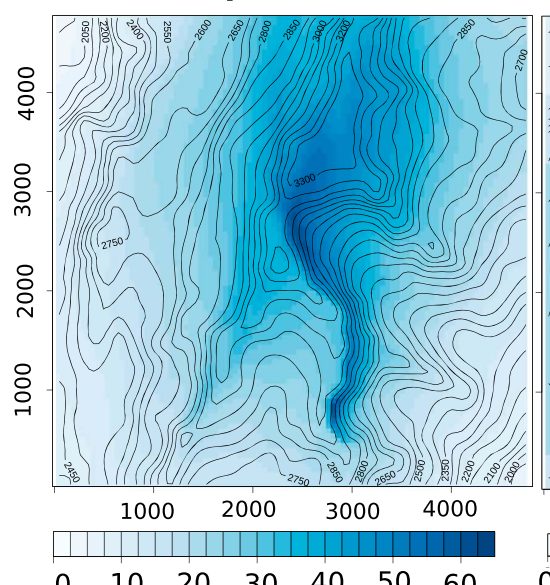

b) Snow

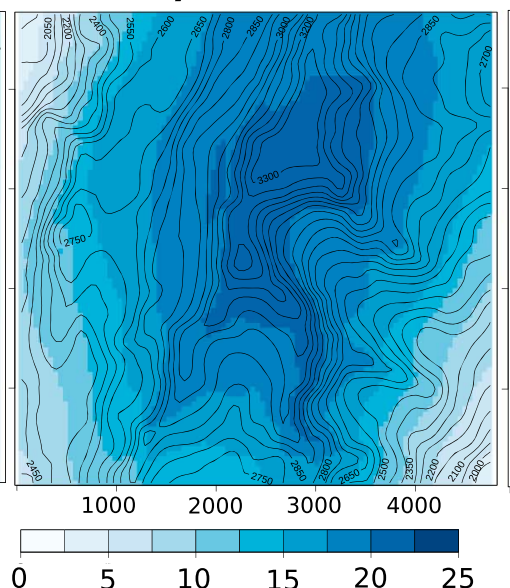

c) Graupel

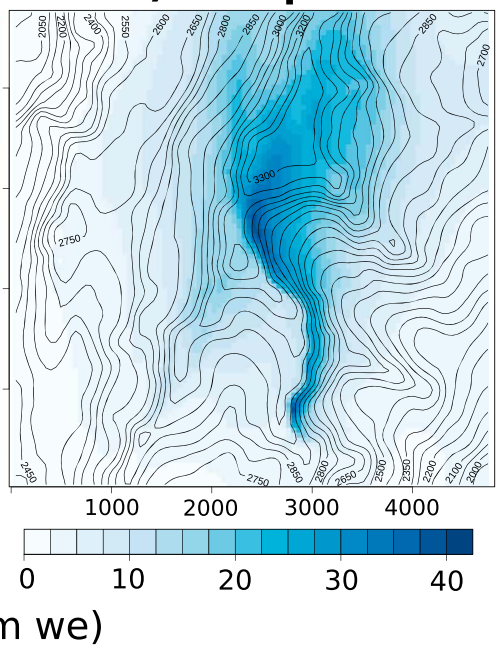

Figure 8. (a) Total amount of solid precipitation, (b) snow aggregates, and (c) graupel between 5 February 12:00 and 14 February 15:00 in simulation CTRL. Note the difference of values in the colorbar between Figures $8 \mathrm{a}$ and $8 \mathrm{~b}$ and $8 \mathrm{c}$. 
Cumulated solid precip. (14/02 15h-15/02 12h)

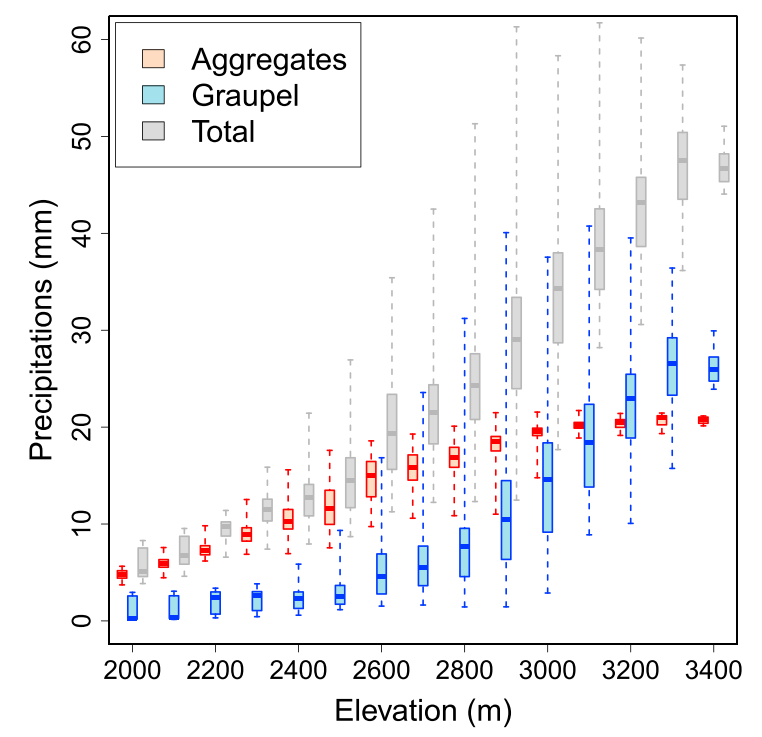

Figure 9. Boxplot of the total amount of snow aggregates (red), graupel (blue), and solid precipitation (grey) per $100 \mathrm{~m}$ elevation bands in simulation CTRL. The ends of the whiskers represent the minimum and maximum of the data of each boxplot.

\subsubsection{Influence of Cloud Microphysical Processes}

For our case study, graupel is the main source of spatial variability of solid precipitation (Figure 8). Compared to snow aggregate, graupel is characterized by a larger settling velocity that can potentially reduce downwind transport (e.g., Zängl, 2007). To gain more understanding on the processes leading to this variability, budget computations were performed in simulation CTRL as in Lascaux et al. (2006) over the period between 08:30 and 09:00 on 15 February and integrated over this $30 \mathrm{~min}$ period. The spatial pattern of graupel accumulation during this period shown in Figure 10a is similar to the pattern of graupel accumulation simulated for the whole event (Figure 8c). A vertical section across the large bowl on the northeastern side of the Pic Blanc is used to illustrate the mean distribution of the different mixing ratios of liquid and solid hydrometeors and associated microphysical processes. This region is characterized by strong vertical velocities (Figure 10b) associated with a large upslope flow. Maxima of vertical velocity are found close to the surface. In these regions, the vertical movement favors condensation and the formation of supercooled liquid droplets (Figure 10d). The presence of these droplets leads to riming of snow aggregates (Figure 10e) and the further growth of graupel by accretion of cloud droplets known as dry growth (Figure 10f) since in this case the surface temperature of graupel remains below freezing point, meaning that there is no wet growth. The absence of raindrop (not shown) prevents the formation of graupel by contact freezing of raindrops with pristine ice crystal. Overall, graupel is mainly located on the windward side of this large basin and extend approximately up to 3,350 m. Maxima of graupel are found near the surface on the windward side of the upper ridge where the cloud droplets mixing ratio is locally maximum. Therefore, the spatial variability of solid precipitation in this simulation is mainly explained by the formation of graupel due to riming of snowflake by the supercooled liquid droplets formed in regions of strong terrain-induced updrafts.

The influence of riming and graupel formation on the spatial distribution of snow accumulation has been highlighted in previous studies using atmospheric simulations at kilometer scale (e.g., Liu et al., 2011; McCormick, 2009). Our study reveals the potential influence of this process at very high resolution $(50 \mathrm{~m})$ in alpine terrain when updrafts are sufficient to sustain the production of local supercooled liquid droplets. This finding is consistent with the observations using polarimetric radar data reported by Mott et al. (2014) who identified local enhancement of snowfall around mountain ridges and summits due to the occurrence of rimed snow aggregates and graupel. Evidence of riming in alpine snowfall has been also reported by Grazioli et al. (2015) even if they do not discuss in details the spatial variability of precipitation generated by riming. The differences in terms of spatial variability between graupel and snow aggregates in our study depend partially on assumptions made in the cloud microphysical scheme used in Meso-NH (Pinty \& Jabouille, 1998). Indeed, the transfer from snow to graupel when riming occurs leads to the direct formation of particles of higher fall speed and directly affects the spatial and temporal variability of snowfall. Using a cloud microphysical scheme accounting for the effects of the different degrees of riming on particle mass and fall speed (Morrison \& Milbrandt, 2015) could potentially modify the spatial distribution of snowfall. Results by McCormick (2009) showed that predicting the effect of riming on particle properties in atmospheric simulation at $1.33 \mathrm{~km}$ grid spacing reduces graupel accumulation on windward slope since rimed snow is transported further than faster falling graupel. Similar effects could be found at $50 \mathrm{~m}$ resolution. Nonetheless, our numerical results provide complementary results to the work of Mott et al. (2014) and suggest that microphysical processes can influence small-scale snowfall pattern in alpine terrain.

\subsubsection{Influence of Preferential Deposition of Snowfall}

The spatial pattern of total amount of snow aggregates in simulation CTRL (Figure 8b) shows that the simulated accumulation of snowflakes for our case study is only slightly influenced by the near-surface flow field (Figure 4). Therefore, for our case study, Meso-NH at $50 \mathrm{~m}$ resolution shows only little evidence of preferential deposition of snowfall (Lehning et al., 2008), i.e., "the spatially varying deposition of precipitation due to topography-induced flow field modification close to the surface." This concept has previously been 
a) Cumulated graupel ( $\mathrm{mm})$

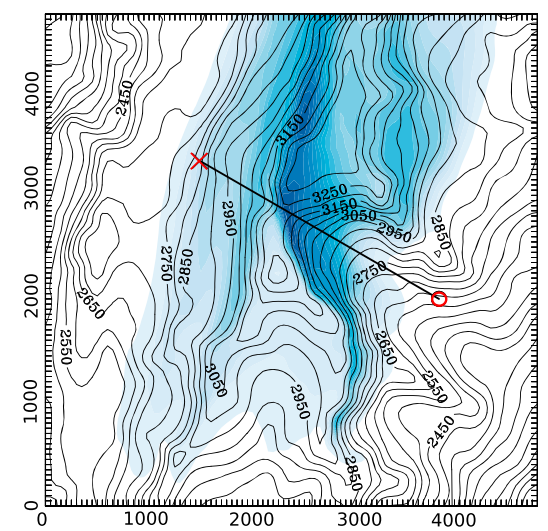

c) Graupel mixing ratio $\left(\mathrm{g} \mathrm{kg}^{-1}\right)$

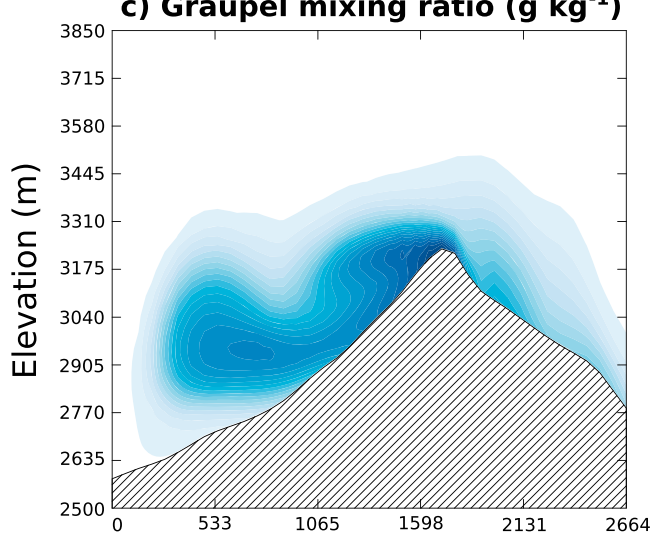

e) Riming rate $\left(10^{-6} \mathrm{~s}^{-1}\right)$

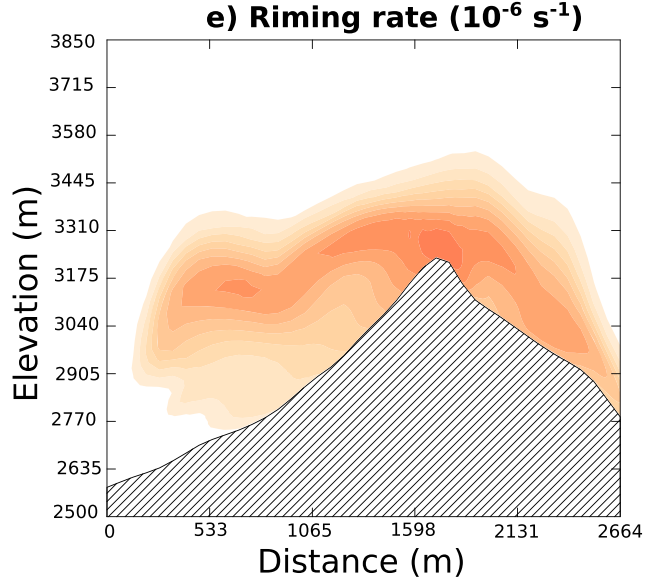

b) Vertical Wind speed $\left(\mathrm{m} \mathrm{s}^{-1}\right)$

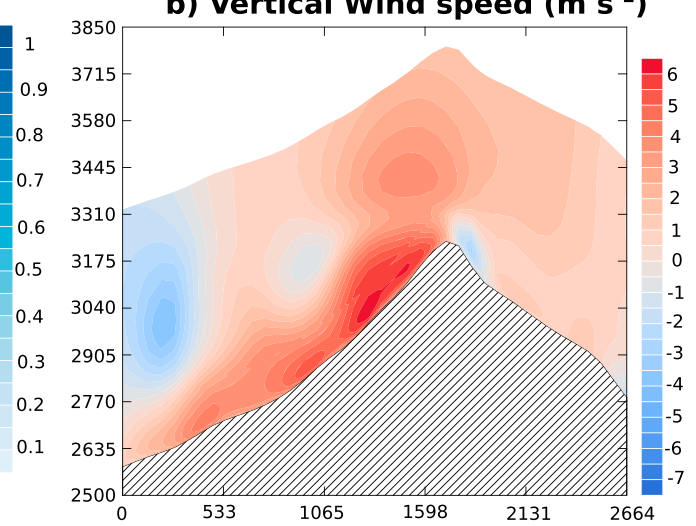

d) Cloud droplets mixing ratio $\left(\mathrm{g} \mathrm{kg}^{-1}\right)$
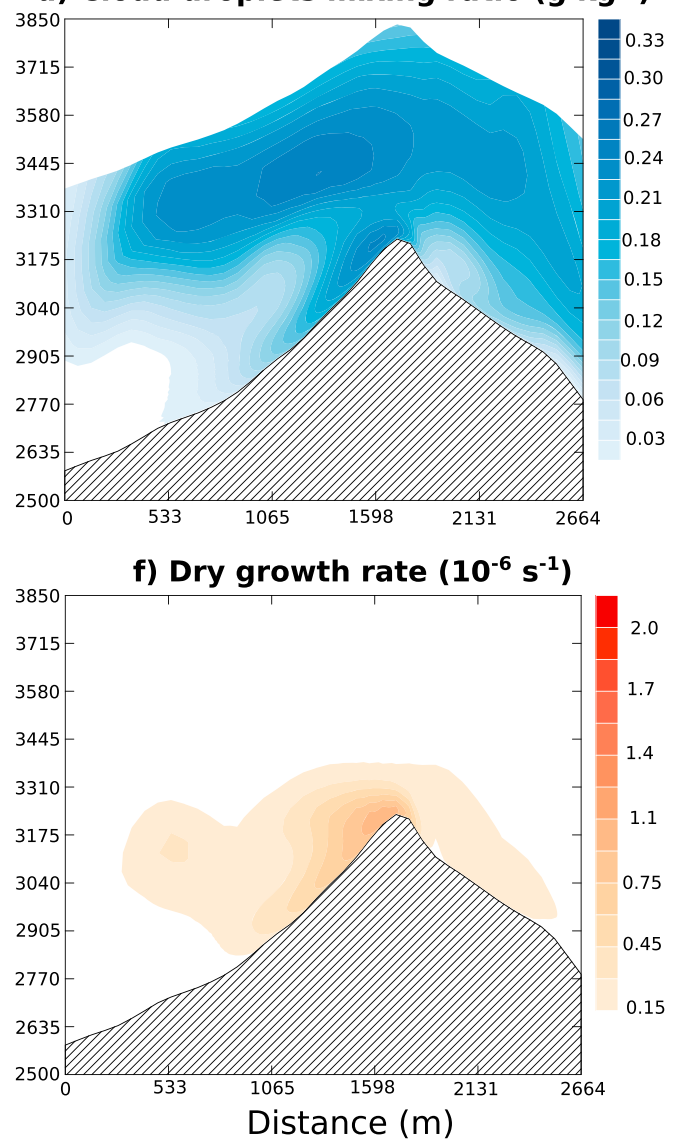

Figure 10. (a) Total amount of graupel in simulation CTRL between 15 February 08:30 and 09:00. The plain black line indicates the location of the vertical cross section (from SE, marked with a red circle, to NW, marked with a red cross) used to represent mean (b) vertical wind speed, (c) graupel and (d) cloud droplets mixing ratio, (e) riming and (f) dry growth rates of graupel production. Vertical cross sections only extend up to $650 \mathrm{~m}$ above the surface.

highlighted by Mott and Lehning (2010) who carried out simulations of snow accumulation accounting only for preferential deposition. At $50 \mathrm{~m}$ grid spacing, they found uniform and enhanced leeward slope loading due to reduced deposition velocities of snow on windward slopes because of high wind speed and updraft and increased deposition velocities leeward of ridges. They used mean flow fields created by a Reynolds-Averaged Navier Stokes approach to drive a stationary advection-diffusion equation for snow particles in the atmosphere. More recently, Wang and Huang (2017) use a three-dimensional LES atmospheric code to simulate wind field at $25 \mathrm{~m}$ resolution and a Lagrangian particle model to track falling snow particles. Their results 
a) Simulation CTRL

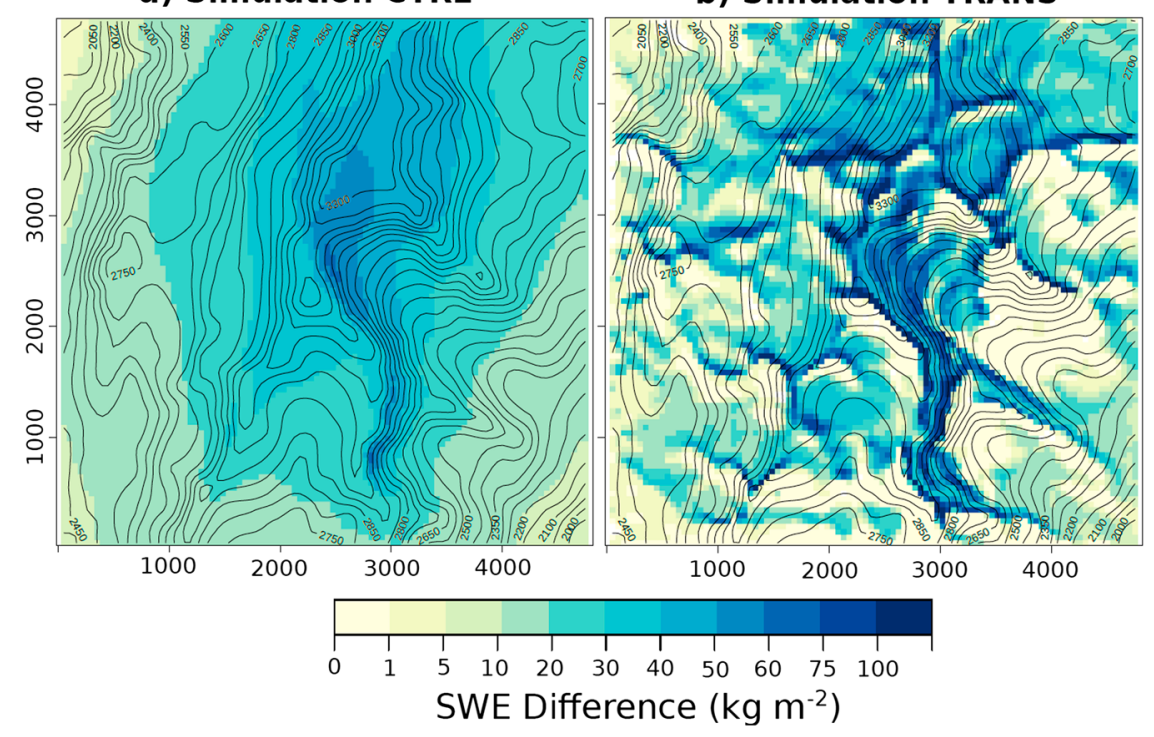

Figure 11. Difference of snow water equivalent $\left(\mathrm{kg} \mathrm{m}^{-2}\right)$ between 15 February 12:00 and 14 February 15:00 in simulations (a) CTRL and (b) TRANS.

illustrate the strong influence of atmospheric stability on simulated snow accumulation with a decrease of spatial variability with increasing stability.

In our study, Meso-NH simulates a nonstationary and turbulent atmospheric flow that evolves at each model time step. It solves the advection of snow aggregates by this flow as well as their settling and microphysical evolution. In LES mode, at $50 \mathrm{~m}$ grid spacing, part of the turbulent flow is explicitly resolved and influences the transport of snow aggregates by the advection scheme. In particular, vertical updrafts reduce their sedimentation and eventually modify their deposition as in Wang and Huang (2017). Despite the fact that Meso-NH includes these effects, simulation CTRL at $50 \mathrm{~m}$ grid spacing shows only little evidence of preferential deposition of snowfall. Several hypotheses can be made to explain this result and the differences with the previous studies mentioned above. In terms of modeling approach, similarly to other atmospheric models, Meso-NH does not include the effects of subgrid turbulence on the settling speed of snow aggregates (Garrett \& Yuter, 2014) which can potentially modify their accumulation. Compared to Lehning et al. (2008) and Wang and Huang (2017), the cloud microphysical scheme in Meso-NH adds source and sink terms for the evolution of snow aggregates. These terms are not present in the studies just mentioned. Particle inertia is also not considered in our model contrary to Wang and Huang (2017). Atmospheric conditions in our case study differ also from the experiments of Mott and Lehning (2010) and Wang and Huang (2017). In particular, the wind speed at crest level is higher in our experiments (typically $10-15 \mathrm{~m} \mathrm{~s}^{-1}$ ) compared to 7-11 $\mathrm{m} \mathrm{s}^{-1}$ in Mott and Lehning (2010) and 3-8 $\mathrm{m} \mathrm{s}^{-1}$ in Wang and Huang (2017). Therefore, additional experiments will be required in the future with Meso- $\mathrm{NH} /$ Crocus to investigate in details the influence of atmospheric conditions and modeling assumptions on near-surface flow and subsequent snowfall deposition.

4.2.4. Influence of Wind-Induced Snow Transport

Figure 11 illustrates the differences of SWE simulated by Crocus between the end and the beginning of our case study, i.e., the snow accumulation, in simulations CTRL and TRANS. For simulation CTRL, the spatial pattern of SWE difference is similar to the spatial pattern of total solid precipitation shown in Figure 8a, whereas in simulation TRANS wind-induced snow transport strongly influences the spatial pattern of snow accumulation. As mentioned earlier, snow transported by wind during this event is made of fresh snow, just deposited from the concurrent snowfall. No redistribution of preexisting snow occurred in simulation TRANS because of the surface state of the snowpack at the beginning of the simulation. Figure $11 \mathrm{~b}$ shows the presence of large zones where snow does not accumulate. Slope breaks located on the leeward side of these areas received large amounts of deposited snow in addition to the falling solid precipitation. The spatial extension of these accumulation zones is generally lower than the extension of the erosion areas and the amount of deposited snow can locally reach $150 \mathrm{~mm}$ (liquid water equivalent) on the leeward sides of some crests. Similar contrasts 


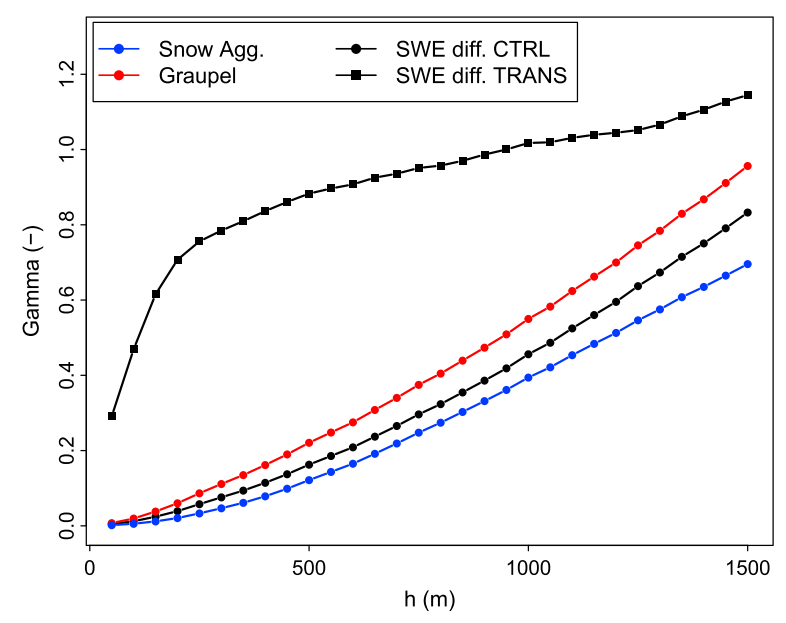

Figure 12. Normalized variogram of the total amount of snow aggregates (blue dots) and graupel (red dots) in simulation CTRL and SWE difference in simulation CRTL (black dots) and TRANS (black square) for our case study. between the extension of erosion and deposition zones have been reported by Trujillo et al. (2016) when studying snow redistribution on sea ice at high resolution $(100 \mathrm{~m} \times 100 \mathrm{~m}$ area).

The analysis of the spatial variability of snow accumulation has been carried out for simulations CTRL and TRANS using spatial variograms (Appendix A). Figure 12 shows the normalized variograms for SWE differences for both simulations. It also includes the normalized variograms for the total amount of graupel and snow aggregates in simulation CTRL. As previously discussed, the variograms confirm that the spatial variability of graupel accumulation is larger than the variability of accumulation of snow aggregates. The differences found between the variograms of SWE difference for simulations CTRL and TRANS clearly show that wind-induced snow transport is the main source of spatial variability of snow accumulation in our case study. Similar conclusions were obtained by Scipión et al. (2013) at the seasonal scale using snowfall pattern derived from a polarimetric X-band radar and snow accumulation pattern obtained with airborne laser scanning.

Results of our simulations at $50 \mathrm{~m}$ grid spacing reveal that wind-induced snow transport is the main source of snow accumulation during a snowfall event. However, we can estimate that Meso-NH/Crocus tends to overestimate the spatial extension of areas where no snow accumulates. This is partially related to the overestimation of blowing snow fluxes which is associated with two main reasons: (i) locally, nearby crests, Meso-NH overestimates the wind speed (see, e.g., Sarennes AWS, Table 3) and thus blowing snow fluxes; (ii) for a given wind speed, the blowing snow scheme overestimates the vertically integrated mass flux when compared with SPC data because of the saltation parameterization and the underestimation of the threshold wind speed for snow transport (Figure 7). The spatial resolution of the simulations has also an influence on the pattern of snow accumulation. Vionnet et al. (2014) have shown that Meso-NH/Crocus is only able to capture the patterns of erosion and deposition at the ridge scale and misses smaller deposition patterns governed by topographic features of scale lower than $50 \mathrm{~m}$. Mott and Lehning (2010) found similar results and showed that Alpine 3D at $50 \mathrm{~m}$ resolution does not simulate snow accumulation on windward slopes (Figure 7 in their study). Sensitivity experiments in their study revealed that for higher grid resolution $(5$ and $10 \mathrm{~m}$ ) large amounts of snow can be deposited on windward slopes, because of a better representation of local topographic features acting as snow traps on these slopes. Therefore, different spatial patterns of snow accumulation are expected at higher grid resolution. Furthermore, avalanches that occur in steep slopes and effect snow distribution (Bernhardt et al., 2012) are not implemented in Meso-NH/Crocus.

\section{Conclusion}

In this paper, we have presented the first high-resolution $(50 \mathrm{~m})$ simulation of a snowfall event in alpine terrain using the fully coupled snowpack/atmosphere model Meso-NH/Crocus. This model explicitly simulates processes affecting snow accumulation in alpine terrain: (i) cloud dynamics and formation of snowfall, (ii) advection of falling snow particles, and (iii) wind-induced snow transport of deposited snow. We selected a snowfall event that occurred in February 2011 in the Grandes Rousses range (French Alps) near the Col du Lac Blanc experimental site. Grid-nesting techniques have been used to propose a dynamical downscaling of meteorological conditions from operational analysis at $2.5 \mathrm{~km}$ resolution down to $50 \mathrm{~m}$ grid spacing over a domain covering the southern part of the Grandes Rousses range with elevation ranging from 1950 to $3465 \mathrm{~m}$ asl. Two sets of simulations with and without wind-induced snow transport have been carried out.

An evaluation of model output at $50 \mathrm{~m}$ grid spacing using meteorological stations in the region showed that Meso-NH/Crocus reproduces satisfyingly well the altitudinal gradient of temperature as well as the evolution of wind speed and direction during our case study. In particular, it captures some typical features of near-surface atmospheric flow in alpine terrain such as the speedup associated with the channeling of the airflow due to the local topography around Col du Lac Blanc. However, the model tends to overestimate speedup along the main crest lines. A main conclusion of this evaluation is that grid-nesting techniques can be applied in alpine terrain to simulate realistic meteorological conditions down to $50 \mathrm{~m}$ grid spacing. A vertical profile 
of three Snow Particle Counters deployed at Col du Lac Blanc measured also blowing snow fluxes during this event and provided an indirect estimation of snowfall amount using the method developed by Naaim-Bouvet et al. (2014). We found that Meso-NH simulates twice the total amount of snowfall derived from SPC data due to an overestimation of snowfall during the first half of our case study. Blowing snow fluxes were also overestimated between 0.1 and $1 \mathrm{~m}$ above the snow surface due to limitation in the parameterization used for the mass flux in the saltation layer and the underestimation of the threshold wind speed.

The spatial variability of simulated snow accumulation and snowfall has then been studied. Snowfall in Meso-NH/Crocus is made of snow aggregates (dry to lightly rimed large ice crystals or snowflakes) and graupel (heavily rimed particles). A detailed analysis showed that the spatial variability of simulated snowfall is mainly explained by the formation of graupel due to riming of snowflake by supercooled liquid droplets formed in regions of strong terrain-induced updrafts. These results are consistent with Mott et al. (2014) and suggest that microphysical processes can influence small-scale snowfall pattern in alpine terrain. Model results show little evidence of preferential deposition of snowfall at $50 \mathrm{~m}$ grid spacing contrary to previous studies in complex terrain (Lehning et al., 2008; Wang \& Huang, 2017) due to different modeling approaches. The simulation including wind-induced snow transport is characterized by a large increase in the variability of snow accumulation compared to the simulation without snow transport as shown on variograms. Despite an overestimation of blowing fluxes, our results suggest that wind-induced snow transport is the main source of spatial variability of snow accumulation in our case study.

Our study illustrates the potential of high-resolution coupled snowpack/atmosphere simulations to quantify the spatial variability of snow accumulation in alpine terrain. Several limitations for this kind of simulation have been also identified in the model, namely, (i) the absence of effects of subgrid turbulence on the settling velocity of solid precipitating hydrometeors, (ii) the apportionment of riming growth between snow and graupel in the cloud microphysical scheme, and (iii) the formulation of the saltation layer and the associated threshold wind speed in the blowing snow scheme. The lack of data to evaluate the spatial variability of simulated snowfall and snow accumulation for this event limits also the ability to analyze model results more deeply. For this reason, future work will include the simulation with Meso-NH/Crocus of snowfall events described in details with polarimetric radar data such as the event studied by Mott et al. (2014). An intercomparison of modeling methods to simulate snow accumulation in mountainous terrain would be also very valuable in a near future.

\section{Appendix A: Spatial Analysis: Variogram}

Acknowledgments

We thank E. Thibert (IRSTEA) for providing data of Sarennes AWS. We also thank E. Brun (ONERC), S. Morin (CNRM/CEN), and Y. Durand (retired from CNRM/CEN) for meaningful scientific discussions. This work has been partially supported by the French INSU LEFE/IDAO program under the INEV project. CNRM/CEN is part of Labex OSUG@2020 (ANR10 LABX56). Col du Lac Blanc is part of the CRYOBS-CLIM observation network (https://cryobsclim.osug.fr/). AROME and SAFRAN analysis are available upon request to Meteo France services. The high-resolution digital elevation models used in the study are freely available for research purpose upon request to the French Geographical Institute (http://professionnels.ign.fr/bdalti). Finally, the Meso-NH software is freely available under CeCILL-C license agreement and can be downloaded at http://mesonh.aero.obs-mip.fr. The wind-induced snow transport module will be included in the upcoming version next year and is currently available upon request to the first author of this paper.
Variograms are widely used to quantify the degree of spatial dependence of a spatial random field (e.g., Webster \& Oliver, 2007). For a field $z$, the variogram can be estimated as follows:

$$
\hat{\gamma}(h)=\frac{1}{2 N(h)} \sum_{i, j \in N(h)}\left(z_{j}-z_{i}\right)^{2}
$$

where $N(h)$ is the set of points pairs $(i, j)$ in each distance class $h$. Following Scipión et al. (2013), normalized variograms were considered in this study to compare variograms for different variables. The normalization is computed by dividing the variogram $\hat{\gamma}(h)$ by the variance of the data. The normalized variogram is expressed as follows:

$$
\widehat{\gamma_{n}}(h)=\frac{1}{2 N(h) V} \sum_{i, j \in N(h)}\left(z_{j}-z_{i}\right)^{2}
$$

where $V$ is the variance of the field $z$ over the considered domain. Variogram analysis has been previously applied to study the spatial variability of snow depth on the ground (e.g., Deems et al., 2006) or snowfall spatial pattern (Scipión et al., 2013).

\section{References}

Asencio, N., \& Stein, J. (2006). Origins of the reversed flow over the windward Alpine foothills during MAP IOP3 and IOP8. Quarterly Journal of the Royal Meteorological Society, 132(615), 297-316.

Aumond, P., Masson, V., Lac, C., Gauvreau, B., Dupont, S., \& Berengier, M. (2013). Including the drag effects of canopies: Real case Large-Eddy simulation studies. Boundary-Layer Meteorology, 146, 65-80.

Bergot, T., Escobar, J., \& Masson, V. (2015). Effect of small scale surface heterogeneities and buildings on radiation fog: Large-Eddy simulation study at Paris-Charles de Gaulle airport. Quarterly Journal of the Royal Meteorological Society, 141, $285-298$. https://doi.org/10.1002/qj.2358

Bernhardt, M., Schulz, K., Liston, G., \& Zängl, G. (2012). The influence of lateral snow redistribution processes on snow melt and sublimation in alpine regions. Journal of Hydrology, 424, 196-206. 
Boone, A., Masson, V., Meyers, T., \& Noilhan, J. (2000). The influence of the inclusion of soil freezing on simulations by a soil-vegetation-atmosphere transfer scheme. Journal of Applied Meteorology, 39, 1544-1569.

Brun, E., David, P., Sudul, M., \& Brunot, G. (1992). A numerical model to simulate snow cover stratigraphy for operational avalanche forecasting. Journal of Glaciology, 38, 13-22.

Carlson, B. Z., Choler, P., Renaud, J., Dedieu, J.-P., \& Thuiller, W. (2015). Modelling snow cover duration improves predictions of functional and taxonomic diversity for alpine plant communities. Annals of Botany, 116(6), 1023-1034.

Choularton, T., \& Perry, S. (1986). A model of the orographic enhancement of snowfall by the seeder-feeder mechanism. Quarterly Journal of the Royal Meteorological Society, 112(472), 335-345.

Chow, F., Weigel, A., Street, R., Rotach, M., \& Xue, M. (2006). High-resolution Large-Eddy simulations of flow in a steep Alpine valley. Part I: Methodology, verification, and sensitivity experiments. Journal of Applied Meteorology and Climatology, 45(1), 63-86.

Colella, P., \& Woodward, P. (1984). The Piecewise Parabolic Method (PPM) for gas-dynamical simulations. Journal of Computational Physics, 54(1), 174-201.

Colle, B. A., Smith, R. B., \& Wesley, D. A. (2013). Theory, observations, and predictions of orographic precipitation. In F. Chow, S. De Wekker, \& B. Snyder (Eds.), Mountain Weather Research and Forecasting (pp. 291 -344). Dordrecht: Springer.

Cuxart, J., Bougeault, P., \& Redelsperger, J. (2000). A turbulence scheme allowing for mesoscale and Large-Eddy simulations. Quarterly Journal of the Royal Meteorological Society, 126(562), 1-30.

Dadic, R., Mott, R., Lehning, M., \& Burlando, P. (2010). Wind influence on snow depth distribution and accumulation over glaciers. Journal of Geophysical Research, 115, F01012. https://doi.org/10.1029/2009JF001261

Deardorff, J. (1972). Numerical investigation of neutral and unstable planetary boundary layers. Journal of the Atmospheric Sciences, 29, $91-115$.

Deems, J. S., Fassnacht, S. R., \& Elder, K. J. (2006). Fractal distribution of snow depth from lidar data. Journal of Hydrometeorology, 7(2), $285-297$.

Deems, J. S., Painter, T. H., \& Finnegan, D. C. (2013). Lidar measurement of snow depth: A review. Journal of Glaciology, 59(215), 467-479.

Durand, Y., Brun, E., Mérindol, L., Guyomarc'h, G., Lesaffre, B., \& Martin, E. (1993). A meteorological estimation of relevant parameters for snow models. Annals of Glaciology, 18, 65-71.

Durand, Y., Guyomarc'h, G., \& Merindol, L. (2001). Numerical experiments of wind transport over a mountainous instrumented site: I. Regional scale. Annals of Glaciology, 32, 187-194.

Filippi, J.-B., Pialat, X., \& Clements, C. B. (2013). Assessment of ForeFire/Meso-NH for wildland fire/atmosphere coupled simulation of the FireFlux experiment. Proceedings of the Combustion Institute, 34(2), 2633-2640.

Garrett, T. J., \& Yuter, S. E. (2014). Observed influence of riming, temperature, and turbulence on the fallspeed of solid precipitation. Geophysical Research Letters, 41, 6515-6522. https://doi.org/10.1002/2014GL061016

Grazioli, J., Lloyd, G., Panziera, L., Hoyle, C. R., Connolly, P. J., Henneberger, J., \& Berne, A. (2015). Polarimetric radar and in situ observations of riming and snowfall microphysics during CLACE 2014. Atmospheric Chemistry and Physics, 15(23), 13,787-13,802.

Groot Zwaaftink, C., Löwe, H., Mott, R., Bavay, M., \& Lehning, M. (2011). Drifting snow sublimation: A high-resolution 3-D model with temperature and moisture feedbacks. Journal of Geophysical Research, 116, D16107. https://doi.org/10.1029/2011JD015754

Groot Zwaaftink, C., Diebold, M., Horender, S., Overney, J., Lieberherr, G., Parlange, M., \& Lehning, M. (2014). Modelling small-scale drifting snow with a Lagrangian stochastic model based on Large-Eddy simulations. Boundary-Layer Meteorology, 153(1), 117-139.

Grünewald, T., Bühler, Y., \& Lehning, M. (2014). Elevation dependency of mountain snow depth. The Cryosphere, 8(6), $2381-2394$.

Guyomarc'h, G., \& Mérindol, L. (1998). Validation of an application for forecasting blowing snow. Annals of Glaciology, 26, $138-143$.

Ishizaka, M., Motoyoshi, H., Yamaguchi, S., Nakai, S., Shiina, T., \& Muramoto, K. (2016). Relationships between snowfall density and solid hydrometeors, based on measured size and fall speed, for snowpack modeling applications. The Cryosphere, 10(6), 2831 -2845.

Kirchner, P., Bales, R., Molotch, N., Flanagan, J., \& Guo, Q. (2014). LiDAR measurement of seasonal snow accumulation along an elevation gradient in the southern Sierra Nevada, California. Hydrology and Earth System Sciences, 18(10), 4261-4275.

Lafore, J., Stein, J., Asencio, N., Bougeault, P., Ducrocq, V., Duron, J., ... de Arellano, J. V.-G. (1998). The Meso-NH atmospheric simulation system. Part I: Adiabatic formulation and control simulations. Annales Geophysicae, 16, 90-109.

Lascaux, F., Richard, E., \& Pinty, J. (2006). Numerical simulations of three different map IOPs and the associated microphysical processes. Quarterly Journal of the Royal Meteorological Society, 132(619), 1907-1926.

Lehning, M., Löwe, H., Ryser, M., \& Raderschall, N. (2008). Inhomogeneous precipitation distribution and snow transport in steep terrain. Water Resources Research, 44(7), W07404.

Liston, G., \& Sturm, M. (1998). A snow-transport model for complex terrain. Journal of Glaciology, 44(148), 498-516.

Liu, Y., Warner, T., Liu, Y., Vincent, C., Wu, W., Mahoney, B., ... Boehnert, J. (2011). Simultaneous nested modeling from the synoptic scale to the LES scale for wind energy applications. Journal of Wind Engineering and Industrial Aerodynamics, 99(4), 308-319.

MacDonald, M., Pomeroy, J., \& Pietroniro, A. (2010). On the importance of sublimation to an alpine snow mass balance in the Canadian Rocky Mountains. Hydrology and Earth System Sciences, 14(7), 1401-1415.

Masson, V., \& Seity, Y. (2009). Including atmospheric layers in vegetation and urban offline surface schemes. Journal of Applied Meteorology and Climatology, 48(7), 1377-1397.

Masson, V., Champeaux, J., Chauvin, F., Meriguet, C., \& Lacaze, R. (2003). A global database of land surface parameters at 1-km resolution in meteorological and climate models. Journal of Climate, 16(9), 1261-1282.

Masson, V., Le Moigne, P., Martin, E., Faroux, S., Alias, A., Alkama, R., ... Voldoire, A. (2013). The SURFEXv7. 2 land and ocean surface platform for coupled or offline simulation of Earth surface variables and fluxes. Geoscientific Model Development, 6(4), 929-960. https://doi.org/10.5194/gmd-6-929-2013

McCormick, H. S. (2009). Observations and modeling of snow over the Washington Cascades, (Master's thesis), USA: Univ. of Washington.

Michioka, T., \& Chow, F. (2008). High-resolution Large-Eddy simulations of scalar transport in atmospheric boundary layer flow over complex terrain. Journal of Applied Meteorology and Climatology, 47(12), 3150-3169.

Morrison, H., \& Milbrandt, J. A. (2015). Parameterization of cloud microphysics based on the prediction of bulk ice particle properties. Part I: Scheme description and idealized tests. Journal of the Atmospheric Sciences, 72(1), 287-311.

Mott, R., \& Lehning, M. (2010). Meteorological modeling of very high-resolution wind fields and snow deposition for mountains. Journal of Hydrometeorology, 11(4), 934-949.

Mott, R., Schirmer, M., Bavay, M., Grünewald, T., \& Lehning, M. (2010). Understanding snow-transport processes shaping the mountain snow-cover. The Cryosphere, 4, 545-559.

Mott, R., Scipion, D., Schneebeli, M., Dawes, N., Berne, A., \& Lehning, M. (2014). Orographic effects on snow deposition patterns in mountainous terrain. Journal of Geophysical Research: Atmospheres, 119, 1419-1439. https://doi.org/10.1002/2013JD019880 
Naaim-Bouvet, F., Bellot, H., \& Naaim, M. (2010). Back analysis of drifting-snow measurements over an instrumented mountainous site. Annals of Glaciology, 51(54), 207-217.

Naaim-Bouvet, F., Bellot, H., Nishimura, K., Genthon, C., Palerme, C., Guyomarc'h, G., \& Vionnet, V. (2014). Detection of snowfall occurrence during blowing snow events using photoelectric sensors. Cold Regions Science and Technology, 106, 11-21.

Noilhan, J., \& Planton, S. (1989). A simple parameterization of land surfaces processes for meteorological models. Monthly Weather Review, $117,536-549$.

Pinty, J., \& Jabouille, P. (1998). A mixed-phase cloud parameterization for use in a mesoscale non-hydrostatic model: Simulations of a squall line and of orographic precipitations, Proceedings of the AMS Conference on Cloud Physics (pp. 217-220). Boston: American Meteorological Society.

Pomeroy, J., \& Gray, D. (1995). Snowcover Accumulation, Relocation and Management, National Hydrology Research Institute Science Report No. 7. Saskatoon, CA: NHRI Environment.

Pomeroy, J., Marsh, P., \& Gray, D. (1997). Application of a distributed blowing snow model to the arctic. Hydrological Processes, 11(11), $1451-1464$.

Prokop, A., Schirmer, M., Rub, M., Lehning, M., \& Stocker, M. (2008). A comparison of measurement methods: Terrestrial laser scanning, tachymetry and snow probing for the determination of the spatial snow-depth distribution on slopes. Annals of Glaciology, 49(1), 210-216.

Raderschall, N., Lehning, M., \& Schär, C. (2008). Fine-scale modeling of the boundary layer wind field over steep topography. Water Resources Research, 44(9), W09425.

Sato, T., Kimura, T., Ishimaru, T., \& Maruyama, T. (1993). Field test of a new Snow-Particle Counter (SPC) system. Annals of Glaciology, 18, $149-154$.

Schirmer, M., Wirz, V., Clifton, A., \& Lehning, M. (2011). Persistence in intra-annual snow depth distribution: 1. Measurements and topographic control. Water Resources Research, 47(9), W09516.

Schön, P., Prokop, A., Vionnet, V., Guyomarc'h, G., Naaim-Bouvet, F., \& Heiser, M. (2015). Improving a terrain-based parameter for the assessment of snow depths with TLS data in the Col du Lac Blanc area. Cold Regions Science and Technology, 114, 15-26.

Schweizer, J., Jamieson, J. B., \& Schneebeli, M. (2003). Snow avalanche formation. Reviews of Geophysics, 41, 1016. https://doi.org/10.1029/2002RG000123

Scipión, D., Mott, R., Lehning, M., Schneebeli, M., \& Berne, A. (2013). Seasonal small-scale spatial variability in alpine snowfall and snow accumulation. Water Resources Research, 49(3), 1446-1457.

Seity, Y., Brousseau, P., Malardel, S., Hello, G., Bénard, P., Bouttier, F., ... Masson, V. (2011). The AROME-France convective-scale operational model. Monthly Weather Review, 139(3), 976-991.

Shu, C.-W. (1998). Essentially non-oscillatory and weighted essentially non-oscillatory schemes for hyperbolic conservation laws. In A. Quarteroni (Ed.), Advanced Numerical Approximation of Nonlinear Hyperbolic Equations (Vol. 1697, pp. 325-432). Berlin: Springer.

Smith, R. B., Jiang, Q., Fearon, M. G., Tabary, P., Dorninger, M., Doyle, J. D., \& Benoit, R. (2003). Orographic precipitation and air mass transformation: An alpine example. Quarterly Journal of the Royal Meteorological Society, 129(588), 433-454.

Sørensen, M. (2004). On the rate of aeolian sand transport. Geomorphology, 59(1), 53-62.

Stein, J. (2004). Exploration of some convective regimes over the alpine orography. Quarterly Journal of the Royal Meteorological Society, 130(597), 481-502.

Stein, J., Richard, E., Lafore, J., Pinty, J., Asencio, N., \& Cosma, S. (2000). High-resolution non-hydrostatic simulations of flash-flood episodes with grid-nesting and ice-phase parameterization. Meteorology and Atmospheric Physics, 72(2), 203-221.

Stoelinga, M. T., Stewart, R. E., Thompson, G., \& Thériault, J. M. (2013). Microphysical processes within winter orographic cloud and precipitation systems. In F. Chow, S. De Wekker, \& B. Snyder (Eds.), Mountain Weather Research and Forecasting (pp. 345-408). Dordrecht: Springer.

Trouvilliez, A., Naaim-Bouvet, F., Bellot, H., Genthon, C., \& Gallée, H. (2015). Evaluation of the FlowCapt acoustic sensor for the aeolian transport of snow. Journal of Atmospheric and Oceanic Technology, 32(9), 1630-1641.

Trujillo, E., Leonard, K., Maksym, T., \& Lehning, M. (2016). Changes in snow distribution and surface topography following a snowstorm on Antarctic sea ice. Journal of Geophysical Research: Earth Surface, 121, 2172-2191. https://doi.org/10.1002/2016JF003893

Vionnet, V. (2012). Etudes du transport de la neige par le vent en conditions alpines: Observations et simulation à l'aide d'un modèle couplé atmosphère/manteau neigeux, (PhD thesis), France: Sciences et Techniques de l'Envitonnement, Université Paris-Est.

Vionnet, V., Brun, E., Morin, S., Boone, A., Faroux, S., Le Moigne, P., ... Willemet, J.-M. (2012). The detailed snowpack scheme Crocus and its implementation in SURFEX v7.2. Geoscientific Model Development, 5, 773-791.

Vionnet, V., Guyomarc'h, G., Naaim Bouvet, F., Martin, E., Durand, Y., Bellot, H., ... Bel, C. (2013). Occurrence of blowing snow events at an alpine site over a 10-year period: Observations and modelling. Advances in Water Resources, 55, 53-63.

Vionnet, V., Martin, E., Masson, V., Guyomarc'h, G., Naaim-Bouvet, F., Prokop, A., ... Lac, C. (2014). Simulation of wind-induced snow transport and sublimation in alpine terrain using a fully coupled snowpack/atmosphere model. The Cryosphere, 8, $395-415$.

Wang, Z., \& Huang, N. (2017). Numerical simulation of the falling snow deposition over complex terrain. Journal of Geophysical Research: Atmospheres, 122, 980-1000. https://doi.org/10.1002/2016JD025316

Webster, R., \& Oliver, M. A. (2007). Geostatistics for Environmental Scientists. Chichester: Wiley.

Weigel, A., Chow, F., Rotach, M., Street, R., \& Xue, M. (2006). High-resolution Large-Eddy simulations of flow in a steep alpine valley. Part II: Flow structure and heat budgets. Journal of Applied Meteorology and Climatology, 45(1), 87-107.

Winstral, A., Elder, K., \& Davis, R. (2002). Spatial snow modeling of wind-redistributed snow using terrain-based parameters. Journal of Hydrometeorology, 3(5), 524-538.

Zängl, G. (2007). Small-scale variability of orographic precipitation in the Alps: Case studies and semi-idealized numerical simulations. Quarterly Journal of the Royal Meteorological Society, 133(628), 1701-1716.

Zängl, G. (2008). The temperature dependence of small-scale orographic precipitation enhancement. Quarterly Journal of the Royal Meteorological Society, 134(634), 1167-1181. 